\title{
Water masses and currents in the upper tropical northeast Atlantic off northwest Africa
}

\author{
Lothar Stramma, Sabine Hüttl, and Jens Schafstall \\ Leibniz-Institut für Meereswissenschaften an der Universität Kiel, IFM-GEOMAR, Kiel, Germany \\ Received 1 March 2005; revised 13 September 2005; accepted 21 September 2005; published 8 December 2005.
}

[1] Recent current measurements in the tropical eastern North Atlantic reproduce the components of the large scale flow field. However, the observations as well as the $1 / 12^{\circ}$-FLAME model computations indicate that a lot of eddy scale variability is superimposed on the mean flow field. Despite of the disturbance by variability the signature of the Guinea Dome is well present. In November 2002 the Guinea Dome transport from direct observations was about $2.8 \mathrm{~Sv}$ above $\sigma_{\theta}=25.8 \mathrm{~kg} / \mathrm{m}^{3}$ and $4 \mathrm{~Sv}$ between $\sigma_{\theta}=25.8$ and $27.1 \mathrm{~kg} / \mathrm{m}^{3}$. The oxygen minimum in the shadow zone comprises the central water and the Antarctic Intermediate Water (AAIW) layers and is located between the equatorial current system and the North Equatorial Current. The North Equatorial Counter- and Undercurrents at $3^{\circ}$ to $6^{\circ} \mathrm{N}$ are major oxygen sources for the central water layer of the low-oxygen regions in the northeastern tropical Atlantic. A second, northern North Equatorial Countercurrent (nNECC) band exists at $8^{\circ}$ to $10^{\circ} \mathrm{N}$. The nNECC carries oxygen rich water from the southern hemisphere eastward but with an admixture of water from the northern hemisphere. A float at $200 \mathrm{~m}$ depth was spreading eastward in the North Equatorial Undercurrent (NEUC), at $28^{\circ} \mathrm{W}$ it shifted northward into the nNECC, and then was trapped in the Guinea Dome region for more than 3 years. The model indicates the region $22^{\circ}$ to $32^{\circ} \mathrm{W}$ as the area of exchange between the NECC/ NEUC and the nNECC bands. In the AAIW layer the northern Intermediate Countercurrent acts as oxygen source for the oxygen minimum zone.

Citation: Stramma, L., S. Hüttl, and J. Schafstall (2005), Water masses and currents in the upper tropical northeast Atlantic off northwest Africa, J. Geophys. Res., 110, C12006, doi:10.1029/2005JC002939.

\section{Introduction}

[2] The tropical eastern North Atlantic off northwest Africa belongs to the less investigated regions in the North Atlantic. The neighboring countries did not had the economic power to carry out large scale physical oceanography investigations, while the European and American countries did preferably work in the subpolar and subtropical gyre as well as in the western tropical Atlantic. Recent climate variability investigations unrevealed that droughts and epidemics in West Africa as well as precipitation in Europe are significantly correlated on time scales of several years with sea surface temperature (SST) variations in the eastern tropical Atlantic. An analysis of Foltz et al. [2003] has shown that the relevant anomalies of the equatorial SST are significantly influenced by oceanic processes. Processes involved are advection, meridional and zonal current divergence and vertical entrainment. Intraseasonal variability by tropical instability waves and the connected eddy fluxes also play a role for the stratification and circulation in this key region. Hence, the eastern North Atlantic off Northwest Africa will become an important region with regard to climate change investigations in the future.

Copyright 2005 by the American Geophysical Union. 0148-0227/05/2005JC002939\$09.00
[3] Different oceanographic regimes exist in the tropical eastern Atlantic. In the open ocean north of the Cape Verde Islands there is the North Equatorial Current (NEC) as southern part of the subtropical gyre. In this region subduction takes place, while near the coast of Mauritania and Senegal as well as in the Guinea Dome south of the Cape Verde Islands upwelling appears [e.g., Schott et al., 2004]. In the equatorial Atlantic there is a permanent tropical circulation that is composed of several zonal current and countercurrent bands of small vertical and meridional extent compared to the subtropical gyres [e.g., Stramma et al., 2003]. The equatorial current system including the North Equatorial Countercurrent (NECC) and the North Equatorial Undercurrent (NEUC) forms the southern part of a tropical gyre. According to the ventilation concept, the renewal of water masses in the main thermocline is archived by isopycnal advection and subduction. According to ventilation models [e.g., Luyten and Stommel, 1986], an unventilated shadow zone lies to the southeast of the subtropical gyre and is not ventilated from the north [e.g., Siedler and Onken, 1996].

[4] The water mass characteristics in the North Atlantic tropical gyre are dominated by low oxygen zones in the central water as well as in the Antarctic Intermediate Water layer. Changes in the oxygen content are subject of speculation, which might lead to changes in the biogeochemistry, 


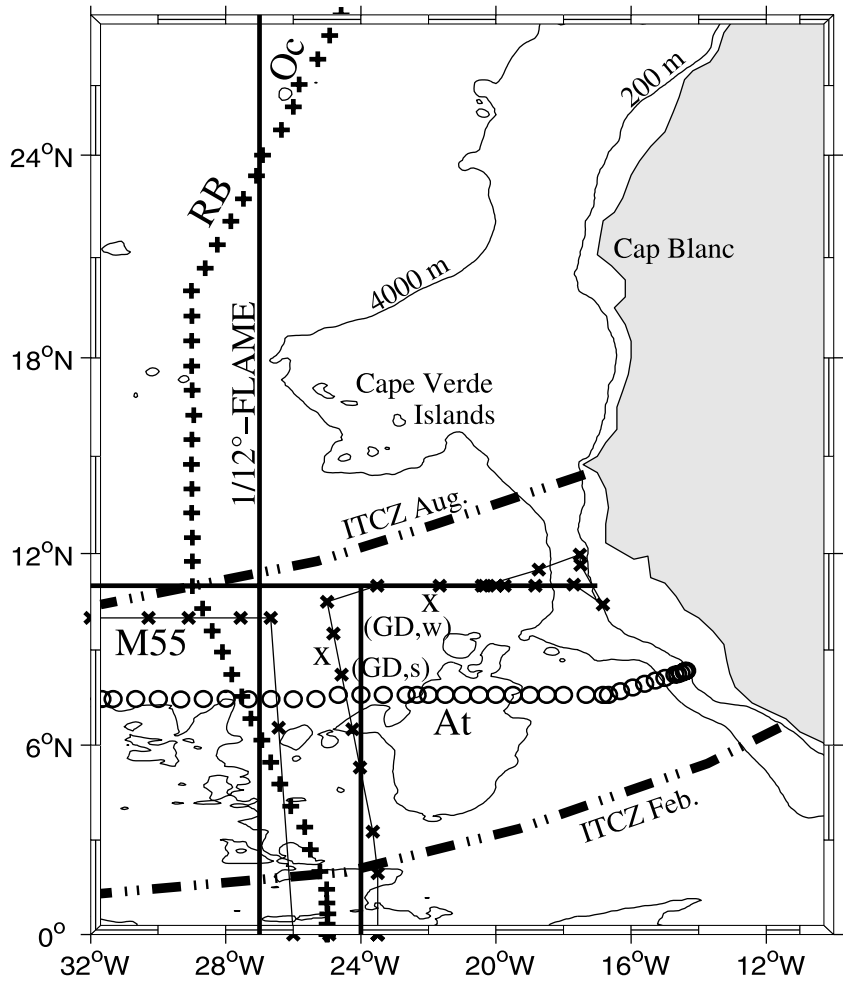

Figure 1. Map of the investigation area with the depth contours of $200 \mathrm{~m}$ and $4000 \mathrm{~m}$ included. Shown are the R/V Meteor cruise M55 stations in October/November 2002 as crosses connected by a thin solid line as well as the CTDlocations of the R/V Oceanus cruise in August 1988 (Oc) by pluses. The R/V Ron Brown cruise in July/August 2003 (RB) is almost identical to the $\mathrm{R} / \mathrm{V}$ Oceanus cruise track. The R/V L'Atalante cruise in February/March 1993 (At) is shown by circles. Sections taken from the $1 / 12^{\circ}$-FLAME model are marked as thick solid lines. Further shown is the center location of the Guinea Dome in boreal summer $(\mathrm{GD}, \mathrm{s})$ and winter $(\mathrm{GD}, \mathrm{w})$ marked by a cross. The northernmost ITCZ location in August and southernmost in February is included as dash-dot-dotted line.

in local fishery catches but may be also interact with climate changes. In biological observations the oxygen minimum zone represents a major oceanographic boundary for many species [Levin, 2003].

[5] In this paper the main focus is on the low oxygen layer in the tropical North Atlantic south of the Cape Verde Islands in the Guinea Dome region and the supply of water to the eastern Atlantic by the zonal current bands. For the large scale interaction some additional information from the region north of the Cape Verde Islands is included. Therefore, the area of investigation reaches from the equator to $28^{\circ} \mathrm{N}$ and from $10^{\circ} \mathrm{W}$ to $32^{\circ} \mathrm{W}$ (Figure 1). This region comprises the central tropical North Atlantic, the Guinea Dome and the southeastern subtropical gyre.

[6] Here we report on recent current measurements and hydrographic observations as the tropical eastern Atlantic off Northwest Africa receives increasing interest due to the relevance of the region for climate variability as well as biogeochemical changes. We combine the observations with earlier results and compare them with numerical computa- tions to better understand the upper ocean circulation and water mass distribution in the eastern tropical North Atlantic.

\section{Material and Methods}

[7] The R/V Meteor cruise M55 was made from Curacao in the Caribbean (12 October 2002) to Duala, Cameroon (19 November 2002). The Meteor expedition comprised a transAtlantic section from west to east along about $10-11^{\circ} \mathrm{N}$, together with a short, mid-ocean meridional excursion to the equator. The return leg from the equator to $11^{\circ} \mathrm{N}$ was located at about $24^{\circ} \mathrm{W}$ (Figure 1). On this leg at $5^{\circ} \mathrm{N}$ the date changed from October to November. The major research interest were biogeochemical investigations [Wallace and Bange, 2004], however also mainly shallow (<650 m) CTD casts were made as well as continuous shipboard ADCP measurements. The CTD casts have wide station spacing. The hydrographic data were used to compute the isopycnals. These isopycnals don't show large depth variability, hence, the derived ADCP transports between isopycnals should not be affected much by the station spacing of the hydrographic stations.

[8] The velocity distribution in the upper ocean was measured during R/V Meteor cruise M55 with a $75-\mathrm{KHz}$ phased-array ADCP named Ocean Surveyor (OS) used for underway measurements of upper ocean currents. The OS ADCP collected single ping data with a vertical resolution of $8 \mathrm{~m}$, with a ping interval of about $2.2 \mathrm{~s}$. The ADCP data have been calibrated for sensitivity and for misalignment between the ADCP axis and the axis of the ships compass. For calibration basically the methods explained by Joyce [1989] were used with some modifications described by Schafstall [2003]. After calibration the single ping data have been averaged to 10 minutes ensembles, which were used to calculate velocity sections on an equidistance grid with horizontal resolution of $0.1^{\circ}$. Due to the fact that the first reliable depth cell was from $22 \mathrm{~m}$ the velocity closer to the surface was estimated by linear extrapolation based on vertical gradients between bin $1(22 \mathrm{~m})$ and $3(38 \mathrm{~m})$.

[9] Additional hydrographic surveys were used. The R/V Oceanus cruise at about $27^{\circ} \mathrm{W}$ was carried out in August 1988 and the CTD stations of this cruise are used to present the meridional salinity distribution. Almost exactly at the same locations of the R/V Oceanus cruise a repeat cruise by $\mathrm{R} / \mathrm{V}$ Ron Brown was made in July/August 2003 and the upper $300 \mathrm{~m}$ of the shipboard ADCP-data were made available in the CLIVAR and Carbon Hydrographic Data Office. Finally, also the ADCP section of the R/V L'Atalante cruise at about $7^{\circ} 30^{\prime} \mathrm{N}$ in February and March 1993 was included (Table 1).

[10] Several APEX floats were deployed in March/April 2000 in the tropical western Atlantic at $35^{\circ} \mathrm{W}$. The APEX floats were programmed for a nine day duty cycle with parking depth of $200 \mathrm{~m}$. After drifting at the duty depth for

Table 1. Date and Ships of the Sections Used

\begin{tabular}{lll}
\hline \multicolumn{1}{c}{ Section } & \multicolumn{1}{c}{ Date } & \multicolumn{1}{c}{ Ship } \\
\hline $10-11^{\circ} \mathrm{N}$ & Oct/Nov 2002 & R/V Meteor \\
$7.5^{\circ} \mathrm{N}$ & Feb/Mar 1993 & $\mathrm{R} / \mathrm{V}$ L'Atalante \\
$\sim 23-29^{\circ} \mathrm{W}$ & Aug 1988 & $\mathrm{R} / \mathrm{V}$ Oceanus \\
$\sim 23-29^{\circ} \mathrm{W}$ & Jul/Aug 2003 & $\mathrm{R} / \mathrm{V}$ Ron Brown \\
$\sim 24^{\circ} \mathrm{W}\left(0-11^{\circ} \mathrm{N}\right)$ & Oct/Nov 2002 & $\mathrm{R} / \mathrm{V}$ Meteor \\
\hline
\end{tabular}


9 days the floats descend to $1500 \mathrm{~m}$, measure a profile of temperature and salinity on their way up to the surface and transmit their position and the profile data via ARGOS during a surface drift of approximately 14 to 20 hours. One float, which still was operating in August 2005, had drifted from the equator at $35^{\circ} \mathrm{W}$ to the Guinea Dome and is used in this presentation.

[11] The observational data were also compared to numerical model simulations based on FLAME (Family of Linked Atlantic Model Experiments). As a conceptual and technical framework for studying various aspects of the Atlantic Ocean, FLAME builds on the type of ocean model as used in CME (Community Modeling Effort [Bryan and Holland, 1989; Böning and Bryan, 1996]) and DYNAMO [Willebrand et al., 2001]. The numerical code used is based on GFDL's (Geophysical Fluid Dynamics Laboratory) Modular Ocean Model MOM2.1 [Pacanowski, 1995], but has experienced numerous modifications. The currently used code is SPFLAME (www.ifm.uni-kiel.de/fb/fb1/tm/ data/pers/ceden/spflame/index.html), a derivative of the original MOM/FLAME code (by C. Eden).

[12] The model domain covers the North Atlantic between $18^{\circ} \mathrm{S}$ and $70^{\circ} \mathrm{N}, 100^{\circ} \mathrm{W}$ and $16^{\circ} \mathrm{E}$. The horizontal resolution is $1 / 12^{\circ}$ and the 46 vertical levels have a thickness of $10 \mathrm{~m}$ near the surface and $250 \mathrm{~m}$ in the depth. The model is forced by monthly mean ECMWF wind stress and heat fluxes [Barnier et al., 1995]. The spinup starts from the Levitus climatology [Boyer and Levitus, 1997] for 9 years. The shown output is from year nine. The northern and southern boundaries are open boundaries. In the north the inflow streamfunction is given by an Arctic model, in the south the streamfunction is given by the Sverdrup relation. For a detailed description of the implementation of the open boundaries in this model, see Czeschel [2004]. The Mediterranian Sea is included west of Corsica/Sardinia. Its eastern boundary is realized as a sponge zone with a strong restoring ( 3 days) to the Levitus climatology. The surface boundary conditions are also given by restoring to the Levitus climatology. The model uses isopycnic mixing $[$ Redi, 1982], biharmonic viscosity and a stability dependent vertical mixing and diffusion scheme after Cummins et al. [1990]. The used mixed layer scheme is from Kraus and Turner [1967].

[13] To supplement the hydrographic observations, satellite altimeter data as well as a hydrographic climatology were used. The altimeter data are the merged data set of Ssalto/Duacs delayed time map of sea level height for November 6, 2002. The low oxygen in the shadow zone is shown by a mean distribution taken from the WOCE Global Hydrographic Climatology [Gouretski and Koltermann, 2004].

\section{Background Information}

[14] Unresolved questions exist for the eastern tropical Atlantic with regard to direct observations and the strength of the Guinea Dome and the oxygen inflow to the low oxygen layers by the zonal equatorial current system. To better understand the results derived here for these unresolved questions some background information from literature for the tropical northeast Atlantic is presented first. The seasonal cycle of the surface currents reflects the responses to the seasonally varying wind fields related to the migration of the Intertropical Convergence Zone [e.g., Stramma and Schott, 1999]. Hence, the atmosphere-ocean interface is of major importance for changes related to climate variability.

[15] In the tropical-subtropical Atlantic, the water masses subducted in the eastern subtropics and inserted into the thermocline by Ekman pumping are characterized by a potential vorticity (PV) minimum [Schott et al., 2004]. The Ekman upwelling associated with the Intertropical Convergence Zone (ITCZ) brings stratified waters with higher PV into the density range of the subducted waters, causing them to make a westward detour around this barrier on their way south [Zhang et al., 2003]. From available near-surface drifter data Grodsky and Carton [2002] found that water which upwelled in the Atlantic cold tongue follows multiple pathways back into the subtropics, but not directly to the subduction zones. Thus the subtropical cells are open to extensive influence from, and exchange with, the subtropical and mid-latitude ocean.

\subsection{Atmosphere-Ocean Interface}

[16] The Atlantic ITCZ shows a marked seasonal migration, moving from its most near-equatorial position during February at about $6^{\circ} \mathrm{N}$ off Africa (Figure 1) to its most northern location near $15^{\circ} \mathrm{N}$ during August [Molinari et al., 1986]. This leads to a variable wind forcing field in the tropical Atlantic north of the equator. At the eastern boundary of the tropical North Atlantic north of the ITCZ the trade winds have an equatorward component, which leads to an offshore Ekman transport. As a result the sea surface is lowered at the coast. The corresponding zonal pressure gradient supports a geostrophic flow towards the equator. The water removed from the coast has to be supplied from below in a narrow region close to the coast. In addition to the zonal pressure gradient produced by the Ekman transport, a meridional pressure gradient must exist caused by a poleward undercurrent [e.g., Hagen, 2001] to support the supply of water for the upwelling process.

[17] Atmosphere-ocean exchange takes place at the sea surface and changes at the sea surface might be related to climate variability. The variability in the south-eastern North Atlantic was investigated from satellite derived sea surface temperature (SST) records [Borges et al., 2004]. The dominant signal found was the annual cycle with $70 \%$ of the SST variance in the region near the Canary Islands, $60 \%$ off Mauritania and Senegal and $40 \%$ west of the Cape Verde Islands. The second dominant signal is a semi-annual cycle. The semi-annual cycle is responsible of making short springs and long autumns.

[18] In the tropical Atlantic, especially on the western side, wave phenomena become important in the observed velocity distributions. The annual cycle in the wind curl field is at maximum north of the equator and leads to the generation of annual off-equatorial Rossby waves [Döös, 1999]. After about 2 months the Rossby waves reach the western boundary of the North Atlantic and they are transformed at the coast of South America into equatorial Kelvin waves, which propagate within nearly one month across the Atlantic Ocean. Tropical instability waves in the Atlantic exist on both sides of the equator and are generated not only in the summer but from May to January [Jochum et al., 
2004]. They are generated by barotropic instability of the shear between the equatorial undercurrent and the northern South Equatorial Current. Foltz et al. [2004] estimated a westward translation for tropical instability waves of $0-$ $40 \mathrm{~cm} / \mathrm{s}$ with a mean of $22 \mathrm{~cm} / \mathrm{s}$.

[19] Schott et al. [2004] presented the Ekman-pumping velocity $\left(\mathrm{w}_{\mathrm{ek}}\right.$; negative is downward) field for the annual mean winds in the Atlantic. In the eastern subtropicaltropical North Atlantic there is an area of positive $\mathrm{w}_{\mathrm{ek}}$. The area integral of positive $\mathrm{w}_{\mathrm{ek}}$ results in an estimate of 4.4 Sv for off-equatorial upwelling in the Guinea Dome and offshore of Northwest Africa [Schott et al., 2004].

\subsection{Currents and the Guinea Dome}

[20] Several zonal currents dominate the flow field of the tropical Atlantic. In the tropical North Atlantic the NECC is known to show a strong seasonal cycle. The NECC shows maximum velocities in August, when the ITCZ is located at the northernmost position, while the NECC is weak in northern spring.

[21] The wind driven subtropical gyre dominates the flow field in the southeastern subtropical North Atlantic in the upper $800 \mathrm{~m}$. In the eastern Atlantic east of $35^{\circ} \mathrm{W}$, the southward flow is organized in three current bands, the first close to the eastern flank of the Mid-Atlantic Ridge, the second in the central Canary Basin and the third close to the eastern boundary off Africa [Stramma, 1984]. The currents at the eastern side are called Canary Current around the Canary Islands and than become the North Equatorial Current when turning southwestward leaving the African continent. Stramma and Siedler [1988] investigated the seasonal variation of the flow field in the eastern subtropical gyre. While there were no significant changes in the magnitude of volume transport, the eastern part of the gyre has a larger east-west and smaller north-south extension in summer compared with the winter season.

[22] According to ventilation models [e.g., Luyten and Stommel, 1986], a shadow zone lies to the south and southeast of the subtropical gyre and is not ventilated from the north. The thermocline circulation in the North Atlantic shadow zone is governed by cyclonic circulation related to an upward displacement of isotherms called the Guinea Dome. The Guinea Dome is a permanent, quasi-stationary feature on the eastern side of the thermal ridge between the NEC and the NECC. The dome is part of the large-scale near-surface flow fields associated with the NEC, the NECC and the NEUC. Siedler et al. [1992] showed that the Guinea Dome exists throughout the year both in subthermocline and thermocline layers that it has a corresponding cyclonic geostrophic flow, and that seasonal changes occur.

[23] The summer and winter mean distributions give upward displacements of the thermocline and pycnocline of typically 30 to $80 \mathrm{~m}$ over horizontal scales of 700 to $1000 \mathrm{~km}$ in the upper $350 \mathrm{~m}$ of the ocean [Siedler et al., 1992]. The related geostrophic flow is cyclonic, with the rotational axis shifting to the southwest with increasing depth. The upper thermocline center of the dome was found at about $9^{\circ} \mathrm{N}, 25^{\circ} \mathrm{W}$, in summer and $10.5^{\circ} \mathrm{N}, 22^{\circ} \mathrm{W}$, in winter (Figure 1). These positions are not well defined because of a double-cell structure apparent in the data in summer [Siedler et al., 1992]. In winter the displacement of isotherms is strongly reduced in the uppermost part of the thermocline, but the displacement magnitude changes little in the thermocline below. The currents at $50 \mathrm{~m}$ depth are typically 5$10 \mathrm{~cm} / \mathrm{s}$, with the weaker flow occurring in winter.

\section{Water Masses}

[24] The water mass distribution in the eastern basins of the North Atlantic had been described by Tsuchiya et al. [1992] presenting a meridional hydrographic section located between $25^{\circ}$ and $29^{\circ} \mathrm{W}$ occupied in July-August 1988 by $\mathrm{R} / \mathrm{V}$ Oceanus. Here, we will summarize the water masses of the upper ocean using the meridional $\mathrm{R} / \mathrm{V}$ Oceanus section from 0 to $28^{\circ} \mathrm{N}$ in the upper $1000 \mathrm{~m}$ (Figure 2a) as well as from a repetition of this section by R/V Ron Brown in July/ August 2003 (Figure 2b).

\subsection{Surface Layer}

[25] In the tropics the surface mixed layer is called Tropical Surface Water (TSW). A shallow salinity maximum exists just below the surface mixed layer in the tropics. This is the Salinity Maximum Water (SMW), which has been also called Subtropical Underwater. It has its origin in the central subtropical gyre (Figure 2a). The saline cores are drifting southwestward with the NEC. The SMW formation rate in the North Atlantic was estimated to be $2 \mathrm{~Sv}$ [O'Connor et al., 2005]. In the domain of this highsalinity water, the oxygen field exhibits a well defined vertical maximum at $30-100 \mathrm{~m}$, with the water above it being supersaturated in summer [Tsuchiya et al., 1992].

[26] Another high-salinity tongue forms at the sea surface near the northern boundary of the NECC. This tongue (Figure $2 \mathrm{a}$ ) extends equatorwards to $2^{\circ} \mathrm{N}$ along $\sigma_{\theta}$ $\sim 24.5 \mathrm{~kg} / \mathrm{m}^{3}$ [Tsuchiya et al., 1992]. The high-salinity core between $9^{\circ} \mathrm{N}$ and $2^{\circ} \mathrm{N}$ is overlaid by low-salinity equatorial surface water associated with high precipitation at these latitudes. No salinity values as high as in the salinity core are found at the sea surface just to the north where the tongue originates. This shows that the high-salinity water contains a significant amount of South Atlantic water that crosses the equator north of Brazil and then feeds the NECC [Tsuchiya et al., 1992]. In the sharp thermocline underneath the TSW, the temperature drops from $25^{\circ} \mathrm{C}$ to $15^{\circ} \mathrm{C}$ over something like $50 \mathrm{~m}$ [Csanady, 1987]. The isopycnal $\sigma_{\theta}=$ $25.8 \mathrm{~kg} / \mathrm{m}^{3}$ [Stramma et al., 2005] is used here as lower boundary of TSW.

\subsection{Central Water}

[27] The central water masses of the North and the South Atlantic are characterized by a nearly linear T-S relationship and are located between the isopycnals $\sigma_{\theta}=25.8 \mathrm{~kg} / \mathrm{m}^{3}$ and $\sigma_{\theta}=27.1 \mathrm{~kg} / \mathrm{m}^{3}$. The Central Water of the North Atlantic is separated into Eastern North Atlantic Central Water (ENACW) and Western North Atlantic Central Water [Emery and Meincke, 1986]. In the region investigated here there is almost exclusively ENACW and we will refer simply to NACW in the following.

[28] The South Atlantic Central Water (SACW) found in the tropical regions contains to a large amount Indian Central Water transferred into the Atlantic Ocean. The NEUC at $4-5^{\circ} \mathrm{N}$ is associated with an isolated subthermocline high-oxygen core (Figure 2b), consistent with the transport of high-oxygen water from the west. The nutrient 

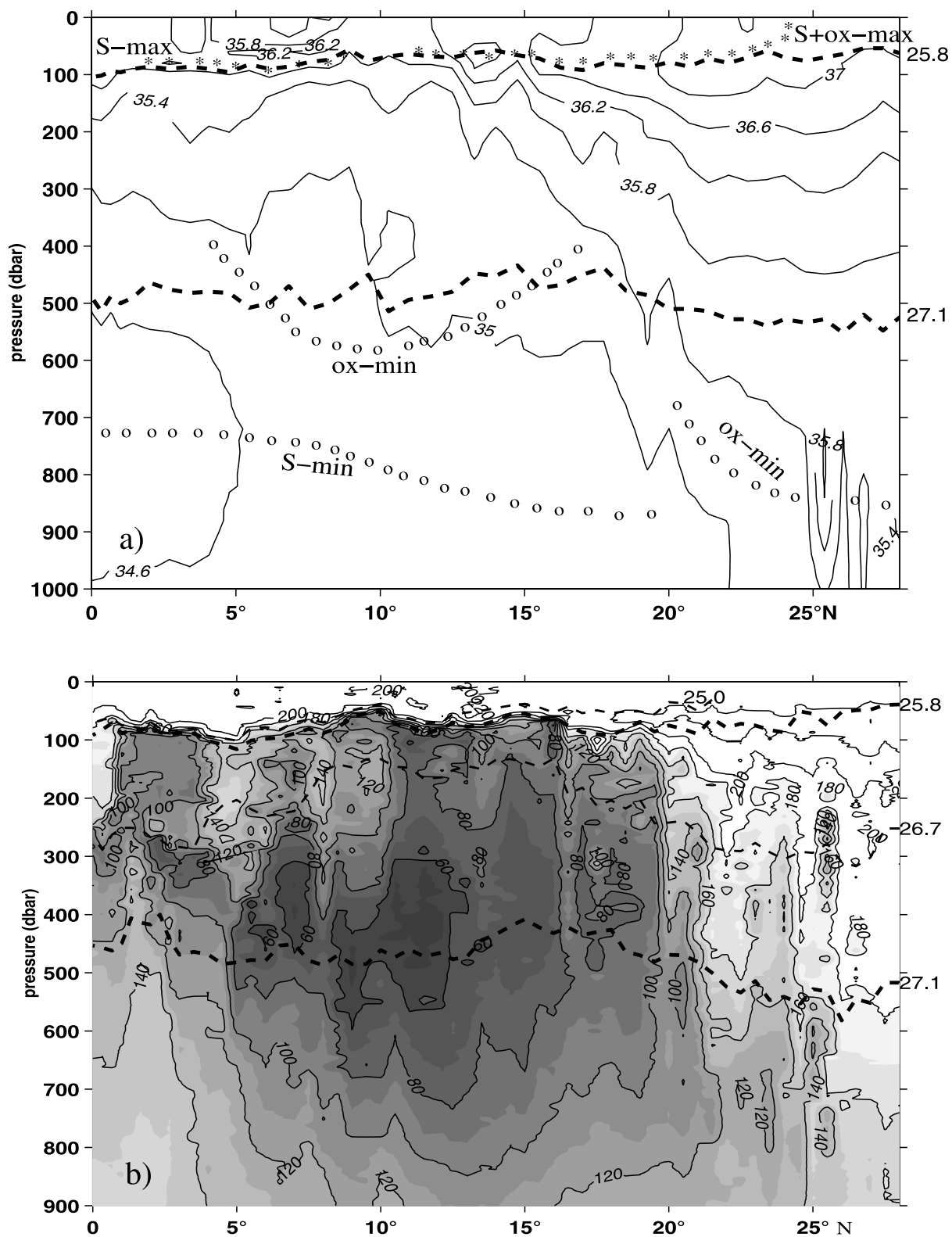

Figure 2. The parameter distribution on a meridional section along about $27^{\circ} \mathrm{W}$ from (a) $\mathrm{R} / \mathrm{V}$ Oceanus in August 1988 for salinity with a contour interval 0.4 and extrema in the salinity and oxygen marked by stars for maximum and circles for minimum and (b) from R/V Ron Brown in July/August 2003 oxygen in $\mu \mathrm{mol} / \mathrm{kg}$ with a contour interval of $20 \mu \mathrm{mol} / \mathrm{kg}$ and gray shading for the low oxygen layer. The water mass boundaries are shown by the isopycnals $\sigma_{\theta}=25.8$ and $27.1 \mathrm{~kg} / \mathrm{m}^{3}$ and in Figure $2 \mathrm{~b}$ also the isopycnals $\sigma_{\theta}=25.0$ and $26.7 \mathrm{~kg} / \mathrm{m}^{3}$ chosen as isopycnal layer to represent the water mass distribution.

fields show only weak minima in the NEUC core [Tsuchiya et al., 1992].

[29] The Cape Verde Frontal Zone (CVFZ) corresponds to the boundary between the NACW and the SACW. The CVFZ is located at about $20^{\circ} \mathrm{N}$ off Africa oriented southwestward to about $16^{\circ} \mathrm{N}$ in the central tropical Atlantic. The front is associated with a convergence at the coast between the Canary Current conveying NACW southward and a northward flow of SACW [Arhan et al., 1994].

[30] With SACW and NACW occupying the same density range, the front is density-compensated and results in a multitude of intrusions, filaments and lenses [Tomczak and Godfrey, 1994]. The NACW is warmer and more saline
(Figure 2a) compared to the SACW. Both central water masses appear in the permanent pycnocline between depths of $150 \mathrm{~m}$ and $600 \mathrm{~m}$ at temperatures greater than about $8^{\circ} \mathrm{C}$. The CVFZ acts as a barrier between the well-ventilated inner part of the subtropical gyre of the North Atlantic and the shadow zone with its low oxygen content [Zenk et al., 1991], visible in the oxygen distribution of Figures $2 b$ and $3 b$.

\subsection{Antarctic Intermediate Water}

[31] The Antarctic Intermediate Water (AAIW) is carried with the subtropical gyre of the South Atlantic towards the tropics. Off Brazil, AAIW is carried into the northern hemisphere and spreads out into the western as well as 

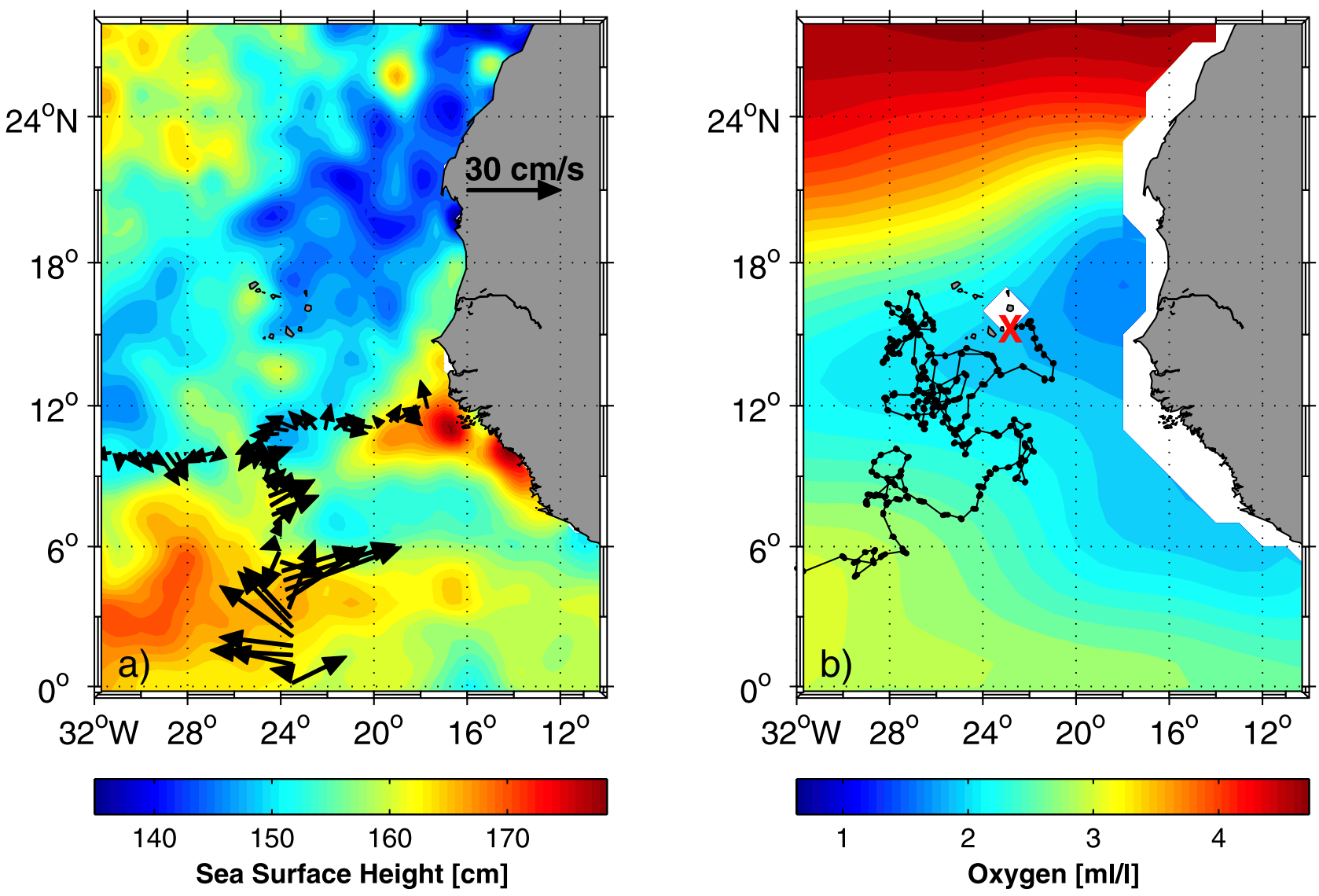

Figure 3. Map of the south-eastern North Atlantic for (a) sea surface height on 6 November 2002 from merged altimeter data provided by AVISO and (b) the mean oxygen distribution in $200 \mathrm{~m}$ depth from WOCE climatology [Gouretski and Koltermann, 2004]. Included in Figure 3a are the current vectors (the data are depth averaged between 30 and $70 \mathrm{~m}$ ) measured during R/V Meteor cruise in October/November 2002. Included in Figure $3 \mathrm{~b}$ is the trajectory of a profiling APEX float (status 28 August 2005) deployed on 12 April 2000 at $0^{\circ} 00.2^{\prime} \mathrm{S}, 35^{\circ} 00^{\prime} \mathrm{W}$ drifting at 200 dbar. The position of the surface drift every 9 days are shown by a series of black dots, and the last surfacing is shown at the end of the trajectory by a red cross.

eastern basins of the North Atlantic. The AAIW is easily identified by low salinities with a salinity minimum at 600 to $900 \mathrm{~m}$ depth (Figure 2a).

[32] From the equator northward, salinity and $\sigma_{\theta}$ increase in the AAIW. Oxygen decreases northward to a minimum at $10-19^{\circ} \mathrm{N}$ [Tsuchiya et al., 1992]. The oxygen distribution is heavily influenced by water from the well-known lowoxygen domain in the eastern equatorial North Atlantic and does not show any vertical extreme in the AAIW south of $20^{\circ} \mathrm{N}$. In July-August 1988 there was a weak oxygen minimum between 22 and $28^{\circ} \mathrm{N}$ (Figure 2a); its continuity was interrupted by Mediterranean Eddies (Meddies) located at $25^{\circ} \mathrm{N}$ and $27^{\circ} \mathrm{N}$. Oxygen, as well as temperature and salinity, increased to the north in the weak minimum, suggesting that it was not a simple northward extension of the stronger AAIW encountered farther south [Tsuchiya et al., 1992].

\section{Results}

[33] Recent ship observations will be used to describe the large scale circulation and water mass distribution in the tropical eastern North Atlantic. Some additional information on the circulation will be derived from satellite data like the altimeter derived sea surface height (Figure 3a). Numerical simulations for the region investigated here from the $1 / 12^{\circ}$ FLAME-model are presented (Figures $4 \mathrm{a}$ and $4 \mathrm{~b}$ ) to show the modeled velocity distribution and salinity field for November on the isopycnal surfaces $\sigma_{\theta}=25.0$ and $26.7 \mathrm{~kg} / \mathrm{m}^{3}$. Hence, these two model distributions represent the density layers of the Salinity Maximum Water and the central waters.

\subsection{Tropical Currents}

[34] The currents in the tropical central and eastern North Atlantic near the surface form the cyclonic tropical gyre made up by the NEC in the north, the NECC to the south, connected by northward flow off Africa in the Guinea Dome. The large seasonal variability in the NECC is visible in the high sea surface height in November 2002 in the region at about $5^{\circ} \mathrm{N}$ west of $16^{\circ} \mathrm{W}$ (Figure $3 \mathrm{a}$ ). In the $1 / 12^{\circ}$ model monthly mean simulation for November (Figures $4 \mathrm{a}$ and $4 \mathrm{~b}$ ) the tropical gyre is not represented by dominant continuous current bands. It is governed instead by short term variability similar to what is seen in the variability of the sea surface height (Figure 3a). However, the annual 

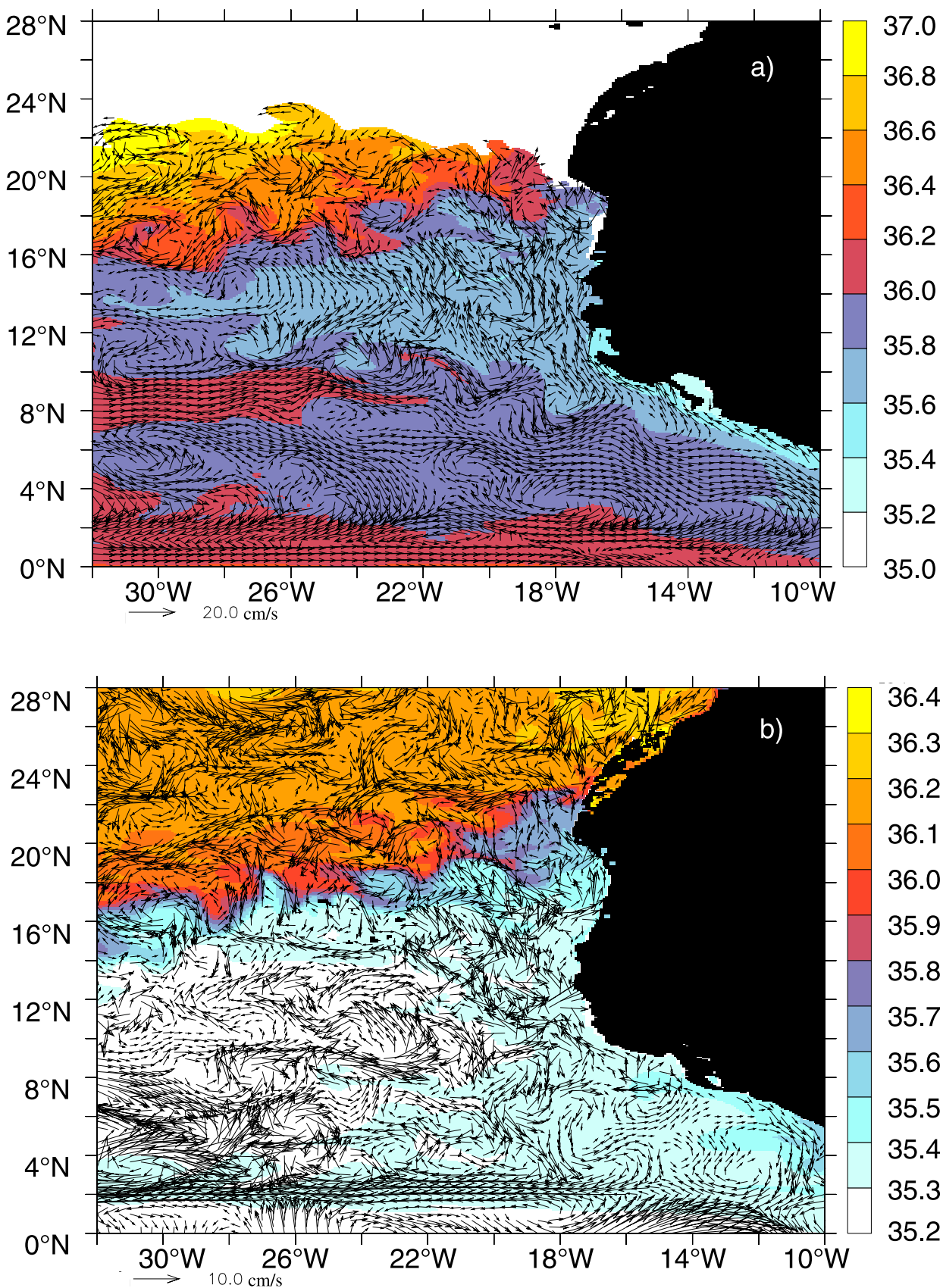

Figure 4. Geographical map of the southeastern North Atlantic with the current vector distribution superimposed on the salinity distribution for November from the model output of the $1 / 12^{\circ}$-FLAME model for (a) the isopycnal $\sigma_{\theta}=25.0 \mathrm{~kg} / \mathrm{m}^{3}$, and for (b) the isopycnal $\sigma_{\theta}=26.7 \mathrm{~kg} / \mathrm{m}^{3}$.

mean $1 / 12^{\circ}$-FLAME velocity distribution on the isopycnal $\sigma_{\theta}=25.0 \mathrm{~kg} / \mathrm{m}^{3}$ (Figure 5) reveals that the tropical gyre exists in the mean.

[35] The ADCP section at about $24^{\circ} \mathrm{W}$ between the equator and $11^{\circ} \mathrm{N}$ in October/November 2002 is compared to the $1 / 12^{\circ}$-FLAME model for November in Figure 6. The direct transport estimates from this section for the layers surface to $\sigma_{\theta}=25.8 \mathrm{~kg} / \mathrm{m}^{3}$ and $\sigma_{\theta}=25.8$ to $27.1 \mathrm{~kg} / \mathrm{m}^{3}$ are shown in Figure 7. According to Richardson and Reverdin [1987] the NECC in fall is located between $4^{\circ}$ and $10^{\circ} \mathrm{N}$. In October/November 2002 the NECC was split in 2 current bands, the NECC at 3 to $5^{\circ} 30^{\prime} \mathrm{N}$ as southern one and the northern NECC (nNECC) at 6 to $10^{\circ} 30^{\prime} \mathrm{N}$ (Figure 6). The southern band is mainly restricted to the upper ocean layer with a transport of about $5 \mathrm{~Sv}$ between $3^{\circ} \mathrm{N}$ and $5^{\circ} 30^{\prime} \mathrm{N}$ above $\sigma_{\theta}=25.8 \mathrm{~kg} / \mathrm{m}^{3}$ (Figure 7). Between $7^{\circ} \mathrm{N}$ and 


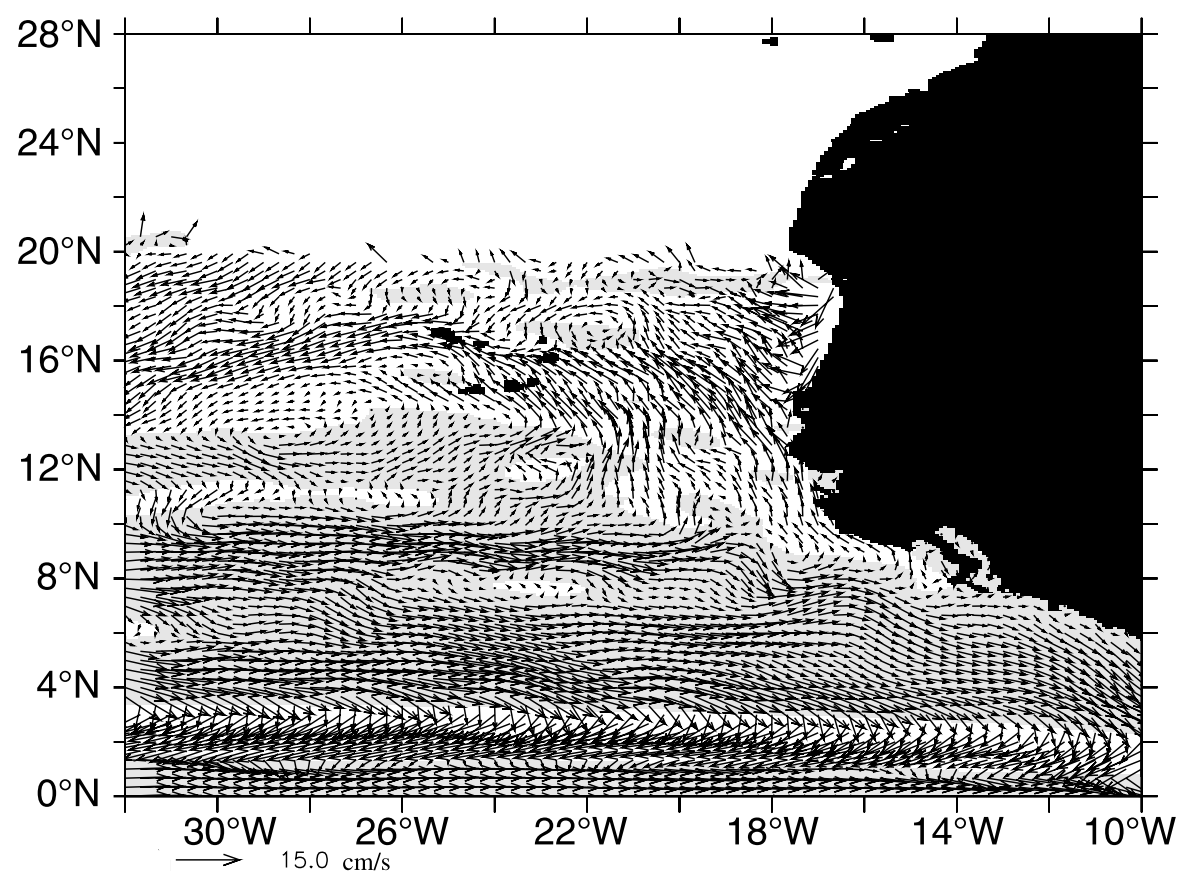

Figure 5. The annual mean current vector distribution on the isopycnal $\sigma_{\theta}=25.0 \mathrm{~kg} / \mathrm{m}^{3}$ (eastward components with gray, westward with white background) from the model output of the $1 / 12^{\circ}$-FLAME mode.

$10^{\circ} 30^{\prime} \mathrm{N}$ in the upper layer 2 more $\mathrm{Sv}$ are transported eastward while in the layer $\sigma_{\theta} 25.8$ to $27.1 \mathrm{~kg} / \mathrm{m}^{3}$ between $8^{\circ} \mathrm{N}$ and $10^{\circ} 30^{\prime} \mathrm{N}$ the eastward transport is $4.5 \mathrm{~Sv}$ (Figure 7 ). In total the NECC transport above $\sigma_{\theta}=27.1 \mathrm{~kg} / \mathrm{m}^{3}$ sums up to $11.5 \mathrm{~Sv}$ in October/November 2002. This is in good agreement to the estimate of Fonseca et al. [2004], who described for the region west of $30^{\circ} \mathrm{W}$ an annual cycle of the NECC with a maximum transport of $12 \mathrm{~Sv}$ occurring in November.

[36] The November mean $1 / 12^{\circ}$-FLAME model velocity at $24^{\circ} \mathrm{W}$ (Figure 6b) shows current bands similar to the observations. However, the NECC is shifted a bit to the north and at depth below $100 \mathrm{~m}$ the model velocities are generally smaller than the direct observations. The model distribution on the isopycnal $25.0 \mathrm{~kg} / \mathrm{m}^{3}$ (Figure $4 \mathrm{a}$ ) indicates a continuation of the NECC to $16^{\circ} \mathrm{W}$ where part of the water turns north. Some water spreads eastward into the Gulf of Guinea and contributes to the Guinea Current. Richardson and Reverdin [1987], who used buoys to investigate the Guinea Current, found that during fall and spring the buoy trajectories showed a direct connection between the NECC and the Guinea Current. Also the annual mean $1 / 12^{\circ}$-FLAME model velocity distribution on $\sigma_{\theta}=$ $25.0 \mathrm{~kg} / \mathrm{m}^{3}$ (Figure 5) shows the eastward flow component towards the Guinea Current. Hence, either the eastward continuation exists the entire year or the transport during the times of eastward flow is so strong that it dominates in the annual mean.

[37] In the $1 / 12^{\circ}$-FLAME model November velocity at $24^{\circ} \mathrm{W}$ (Figure $6 \mathrm{~b}$ ) there is the westward flowing northern band of the South Equatorial Current (nSEC). It is located to the south of the NECC and to the north of the Equatorial Undercurrent (EUC) which has its core at the equator. In the observations in October/November 2002 the nSEC trans- ports $4.3 \mathrm{~Sv}$ westward at $24^{\circ} \mathrm{W}$ above $\sigma_{\theta}=25.8 \mathrm{~kg} / \mathrm{m}^{3}$ between $0^{\circ} 30^{\prime} \mathrm{N}$ and $3^{\circ} 15^{\prime} \mathrm{N}$. According to the $\mathrm{SSH}$ on 6 November 2002 (Figure 3a) the strong nSEC is caused by enhanced SSH located just at the $24^{\circ} \mathrm{W}$ section. In the annual mean (Figure 5) the nSEC is present as a continuous current band across the entire region shown with westward (white background) flow direction.

[38] Located at $3^{\circ}-5^{\circ} \mathrm{N}$ at subsurface depth and connected sometimes in northern fall to the NECC is the North Equatorial Undercurrent (NEUC) in the depth range 100 to $300 \mathrm{~m}$. In October/November 2002 there was only a weak NEUC signature in the observations (Figure 6a). It is similar weak in the November $1 / 12^{\circ}$ FLAME-model results, although a current core not resolved in Figure $6 \mathrm{~b}$ exists. In the July/August 2003 observations and the July $1 / 12^{\circ}$ FLAME model (Figure 8) there is the clear signature of the NEUC at 3 to $5^{\circ} \mathrm{N}$. The NEUC and NECC in July/ August 2003 are connected to the higher oxygen content in the upper 300 to $400 \mathrm{~m}$ between 4 and $6^{\circ} \mathrm{N}$ (Figure 2b). Bourles et al. [2002] described that the NEUC shifts northward from $4^{\circ} \mathrm{N}$ at $35^{\circ} \mathrm{W}$ to $5^{\circ} 30^{\prime} \mathrm{N}$ at $23^{\circ} \mathrm{W}$ in July to August 1999. Also APEX floats at $200 \mathrm{~m}$ depth [Schott et al., 2002, Figure 3b] located in the NEUC clearly shift from south of $5^{\circ} \mathrm{N}$ west of $35^{\circ} \mathrm{W}$ to north of $5^{\circ} \mathrm{N}$ on its way eastward. In the observations in October/November 2002, as well as in the model simulation (Figure 6) there is a current band at 5 to $6^{\circ} \mathrm{N}$, and this current band might be viewed as a part of the NEUC. As the model floats show a clear connection between the NECC/NEUC and the nNECC, probably also the NEUC is shifted northward. However, from a single section it is not possible to distinguish whether this is a continuous current band, and the model results show too much eddy variability to clearly define this current band as being the NEUC. 

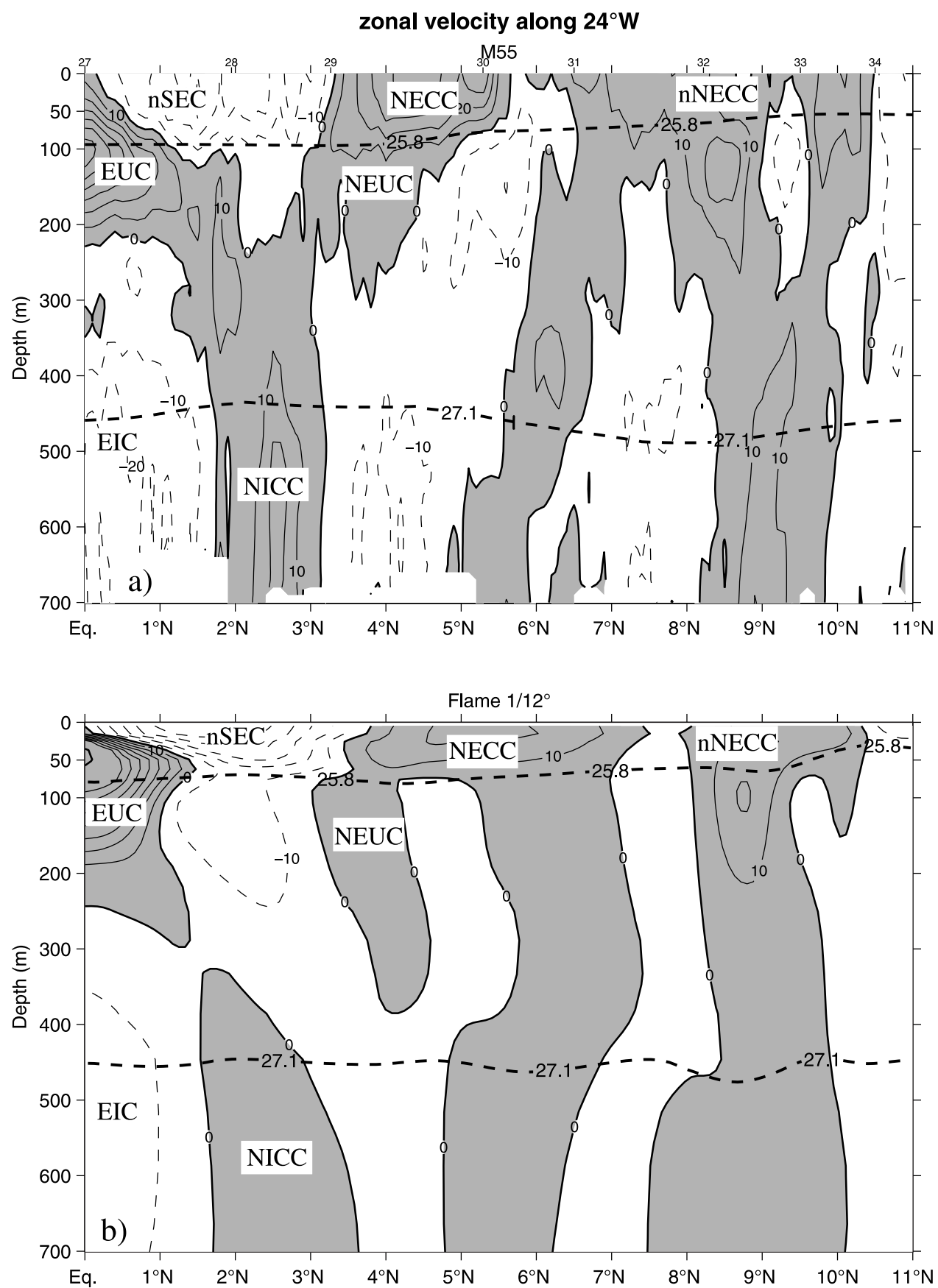

Figure 6. Distribution of zonal velocity in $\mathrm{cm} / \mathrm{s}$ in the upper $700 \mathrm{~m}$ (a) along about $24^{\circ} \mathrm{W}$ in October/ November 2002 from shipboard ADCP measurements and (b) along $24^{\circ} \mathrm{W}$ for November from the $1 / 12^{\circ}$ FLAME model. Positive (eastward) is shown in gray. Included are the density surfaces $\sigma_{\theta}=25.8$ and 27.1 $\mathrm{kg} / \mathrm{m}^{3}$ as thick dashed lines representing water mass boundaries. Some current bands are marked by abbreviations (see text for details).

[39] North of the NECC and NEUC there is a second nNECC band. It reaches downward into the AAIW layer and northward to $10^{\circ} 30^{\prime} \mathrm{N}$ at $24^{\circ} \mathrm{W}$ and $11^{\circ} 30^{\prime} \mathrm{N}$ at $27^{\circ} \mathrm{W}$, both in the observations as well as in the $1 / 12^{\circ}$-FLAME model. Urbano et al. [2005] "rediscovered" the nNECC at $35^{\circ} \mathrm{W}$, after it had been described already from model results in the western tropical Atlantic in 1991 [Schott and Böning, 1991]. In the surface drifter data of Richardson and Reverdin [1987, Figure 11] two separate NECC cores between $33^{\circ} \mathrm{W}$ and $23^{\circ} \mathrm{W}$ exist for March to May and for July to September. Urbano et al. [2005] described that the two cores of the NECC are in Sverdrup balance, therefore they must be generated by the particular structure of the wind field. Consequently, the two cores are the direct result of the finite width of the Inter-tropical Convergence Zone, which has two curvature maxima of the zonal wind stress. No corresponding two core NECC has been found in the Pacific [Urbano et al., 2005]. 


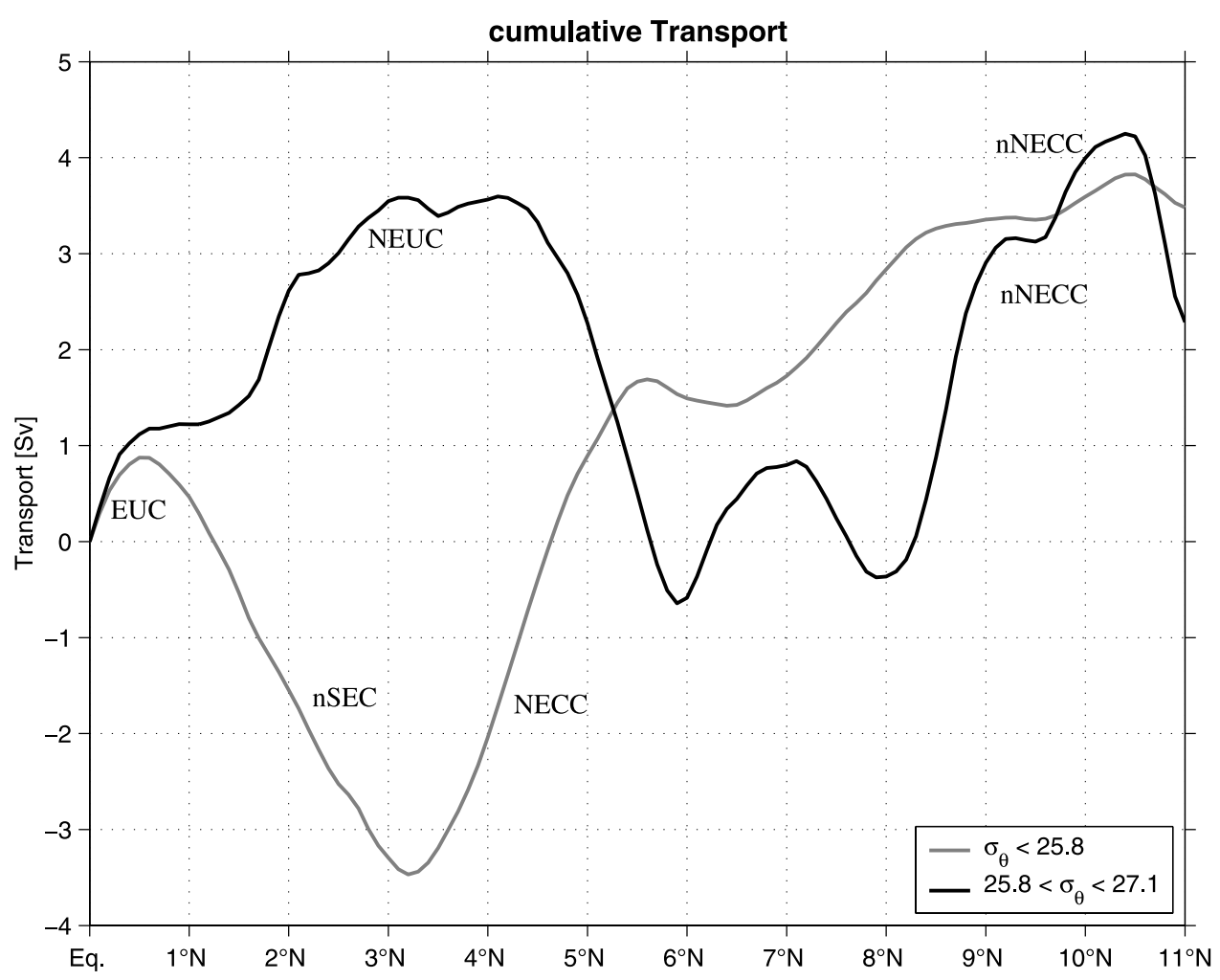

Figure 7. Cumulative volume transport in $\mathrm{Sv}$ (eastward is positive) along the $24^{\circ} \mathrm{W}$ section for the layer surface to $\sigma_{\theta}=25.8 \mathrm{~kg} / \mathrm{m}^{3}$ and the density layer $\sigma_{\theta}=25.8$ to $27.1 \mathrm{~kg} / \mathrm{m}^{3}$. Some current bands represented by the transport changes in the selected layer are marked by abbreviations (see text for details).

[40] The hydrographic section of the July/August 2003 cruise shows high oxygen regions at 9 to $11^{\circ} \mathrm{N}$ (Figure $2 \mathrm{~b}$ ), well related to the eastward flowing nNECC shown in Figure 8a. A similar high oxygen region south of $10^{\circ} \mathrm{N}$ had been observed in the August 1988 oxygen distribution [Tsuchiya et al., 1992]. Therefore, the nNECC at about 8 to $10^{\circ} \mathrm{N}$ seems to be a permanent current band. Although the observational evidence is sparse the annual mean velocity distribution at $24^{\circ} \mathrm{W}$ from the $1 / 12^{\circ}$-FLAME model (Figure 9) shows both current bands, hence in the mean both NECC bands exist.

[41] Backward integration in the FLAME model from water parcels reaching the Guinea Dome provides information on the splitting of the NECC (Figure 10). Most of the model floats shift from the NEUC into the southern subsurface part of the nNECC with some westward detour between $22^{\circ} \mathrm{W}$ and $32^{\circ} \mathrm{W}$. Test runs with model floats from monthly mean model fields showed that the nNECC exists the entire year, although with varying transports. A check of the annual cycle at different sections and depths confirmed this too. Hence, it seems meaningful to derive the backward trajectories from the yearly average circulation. The monthly test runs showed enhanced northward shift during boreal summer months. Therefore, tropical instability waves might be an important mechanism in the transfer from the NECC/NEUC to the nNECC. The more northern floats (Figure 10) show a continuous nNECC flow from the western Atlantic. Near the western boundary the northern NECC is formed and overlaid by NBC retroflection rings. The northward shift of the ITCZ in boreal summer favours an increased eastward current during June to October.
[42] A profiling APEX float was deployed in April 2000 at the equator at $35^{\circ} \mathrm{W}$ and drifted at $200 \mathrm{~m}$ depth (Figure 3b). After its deployment at the equator it was first advected northwestward with the EIC and the SEC. At $40^{\circ} \mathrm{W}$ and $2^{\circ} \mathrm{N}$ it suddenly turned northward and at $4^{\circ} \mathrm{N}$ the float was introduced into the NEUC and moved eastward [Stramma et al., 2003, Figure 9a]. On 22 August 2000 the float crossed $32^{\circ} \mathrm{W}$ eastward and entered the investigation region (Figure 3b). On 12 November 2000 at $27^{\circ} 30^{\prime} \mathrm{W}$ the float suddenly changed its flow direction to northward and shifted into the nNECC band at 8 to $10^{\circ} \mathrm{N}$ where it performed two anticyclonic loops until August 2001. Similar to the model floats, this real float also performed the northward shift, except that it did not such a wide westward detour as derived for the model floats. A look at sea surface height anomaly (SSHA) from the Aviso altimetry data center showed on 15 November 2000 a positive SSHA of about $10 \mathrm{~cm}$ located at $3^{\circ} \mathrm{N}$ to $9^{\circ} \mathrm{N}, 25$ to $30^{\circ} \mathrm{W}$, and the float moved northward on the western side of the SSHA. This eddy moved slowly westward in time. On 13 September 2000 the center was located at $7^{\circ} \mathrm{N} 27^{\circ} \mathrm{W}$ and on 7 March 2001 the center was located at $7^{\circ} \mathrm{N}, 33^{\circ} \mathrm{W}$. The westward spreading of six degrees in six months is too slow that it is a Rossby wave or a tropical instability wave.

[43] The model simulation shows higher salinity at $8^{\circ}$ to $10^{\circ} \mathrm{N}$ then in the surrounding regions on the isopycnal $\sigma_{\theta}=$ $25.0 \mathrm{~kg} / \mathrm{m}^{3}$ (Figure $4 \mathrm{a}$ ) and lower salinity on the isopycnal $\sigma_{\theta}=26.7 \mathrm{~kg} / \mathrm{m}^{3}$ (Figure $4 \mathrm{~b}$ ). The model results for the western basin [Stramma et al., 2005, Figures 9a and 9b] show that for both isopycnals the flow at $8^{\circ}$ to $10^{\circ} \mathrm{N}$ is composed of water from the southern hemisphere. There is, 


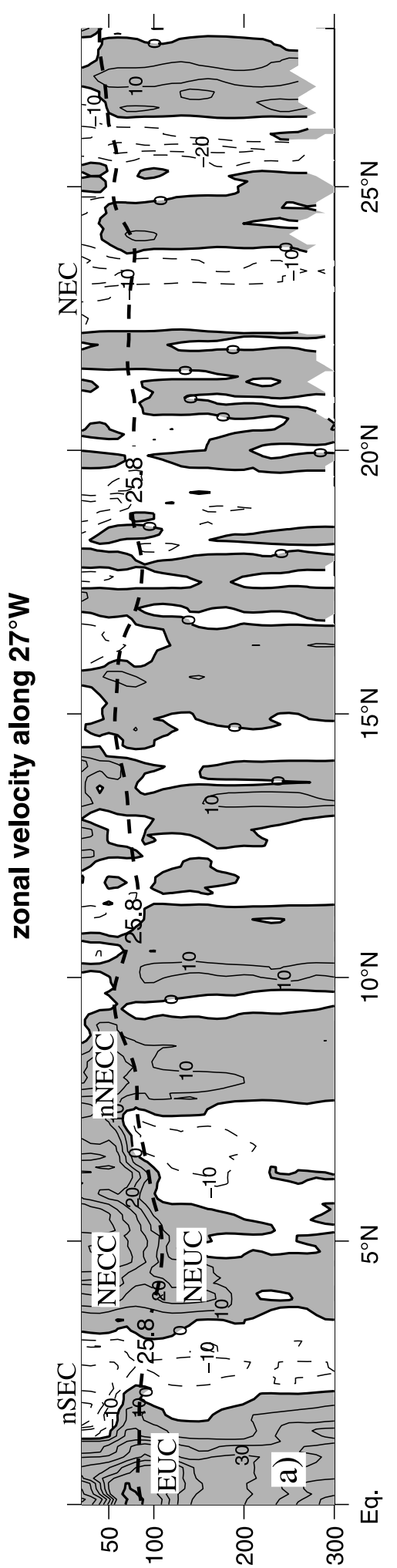

(u) पıdə0

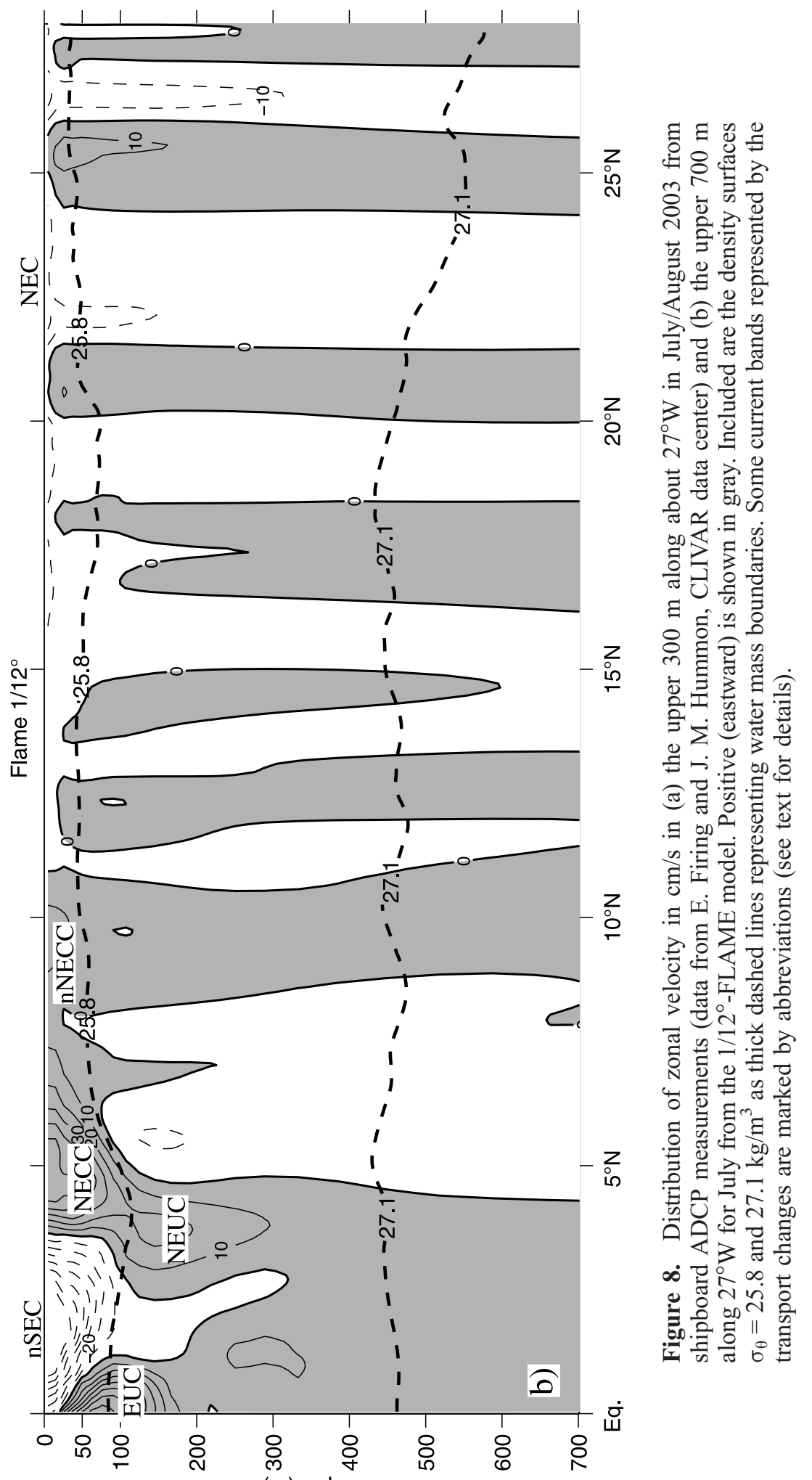

(u) पldəa 


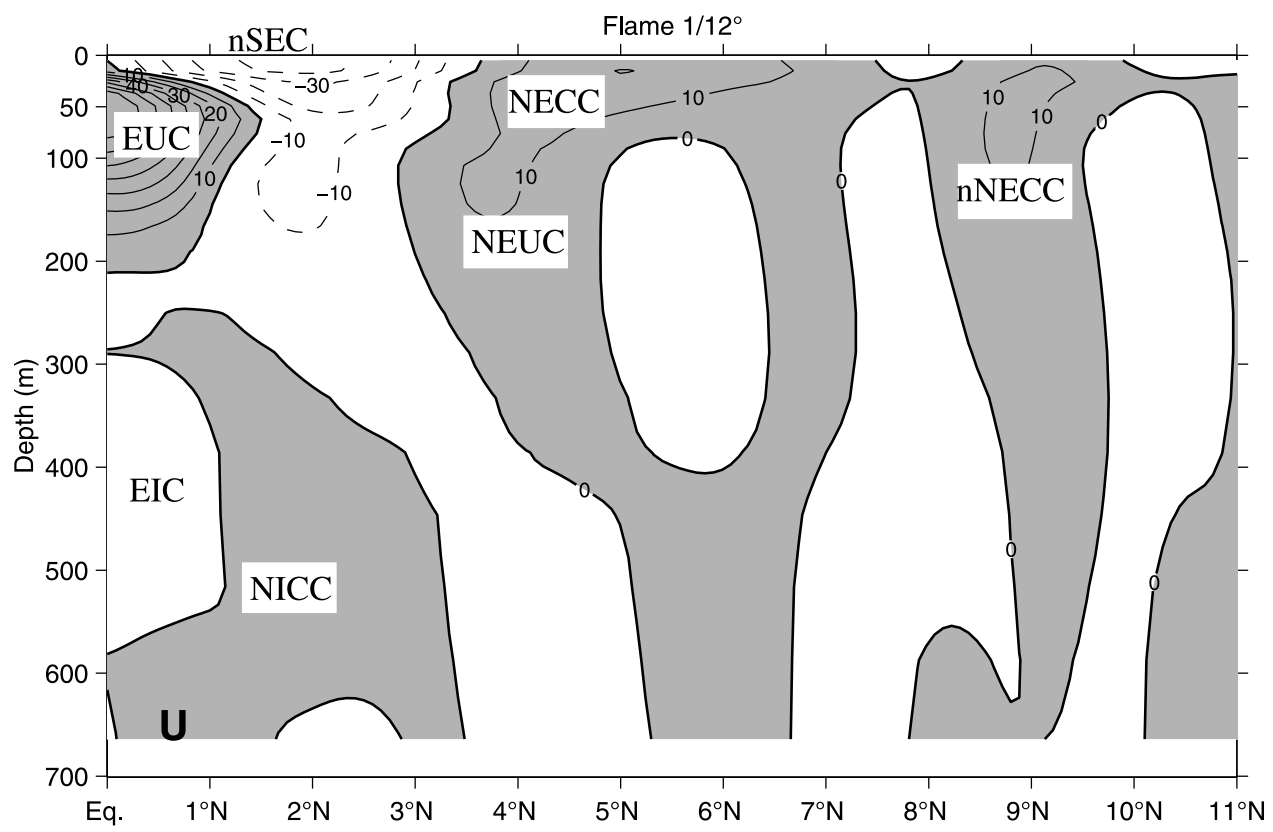

Figure 9. Distribution of zonal velocity in $\mathrm{cm} / \mathrm{s}$ in the upper $700 \mathrm{~m}$ along $24^{\circ} \mathrm{W}$ for the annual mean from the $1 / 12^{\circ}$-FLAME model. Positive (eastward) is shown in gray. Some current bands represented by the transport changes are marked by abbreviations (see text for details).

however, a contribution from the northern hemisphere while the NECC and NEUC are carrying mainly water masses from the southern hemisphere. Hence, the NEUC and NECC as well as the nNECC at about 8 to $10^{\circ} \mathrm{N}$ are major oxygen sources for the low-oxygen regions in the central water layer in the northeastern tropical Atlantic.

[44] At the equator below the EUC observations always show a westward flow in the AAIW layer, called the Equatorial Intermediate Current (EIC). For November both the observations as well as the model clearly show the EIC at $24^{\circ} \mathrm{W}$ (Figure 6). At $27^{\circ} \mathrm{W}$ in July the current observations do not reach to the AAIW layer depth and the model does not show the EIC (Figure 8). The EIC is known to change its vertical and horizontal extent [Schott et al., 1998]. Numerical models show Rossby beams generated by the reflection of Kelvin beams at the eastern boundary causing seasonality in the depth range of the EIC [Brandt and Eden, 2005]. Therefore, the EIC is present in the model sections from about October through June. Nevertheless, in the annual mean $1 / 12^{\circ}$-model distribution (Figure 9), the signature of the EIC is present.

[45] North of the EIC the Northern Intermediate Countercurrent (NICC) should be located between at 400 to $1000 \mathrm{~m}$ depth and $1^{\circ} \mathrm{N}$ to $3^{\circ} \mathrm{N}$ [Schott et al., 1995]. In the observations in October/November 2002 the NICC is strong and reaches $20 \mathrm{~cm} / \mathrm{s}$ at 500 to $700 \mathrm{~m}$ depth (Figure 6). The

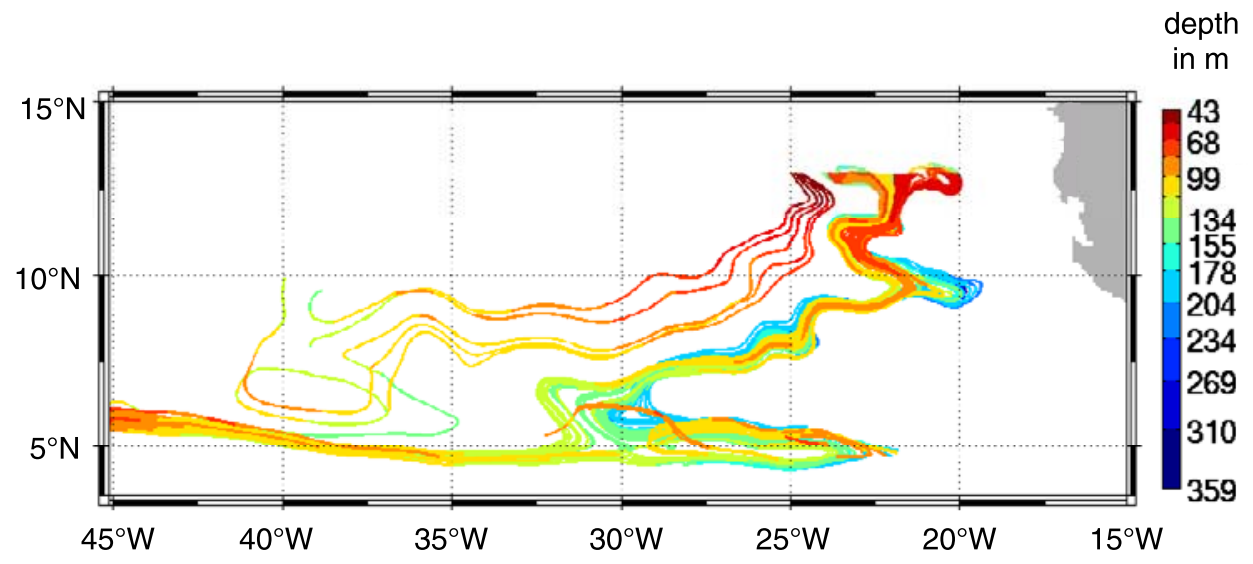

Figure 10. Distribution of model float trajectories launched in the Guinea Dome. The floats were inserted at $13^{\circ} \mathrm{N}, 20$ to $25^{\circ} \mathrm{W}$ in depths between $50 \mathrm{~m}$ and $150 \mathrm{~m}$ and integrated backward in time for four years with the annual mean model velocity fields. The depth of the floats is color-coded. 

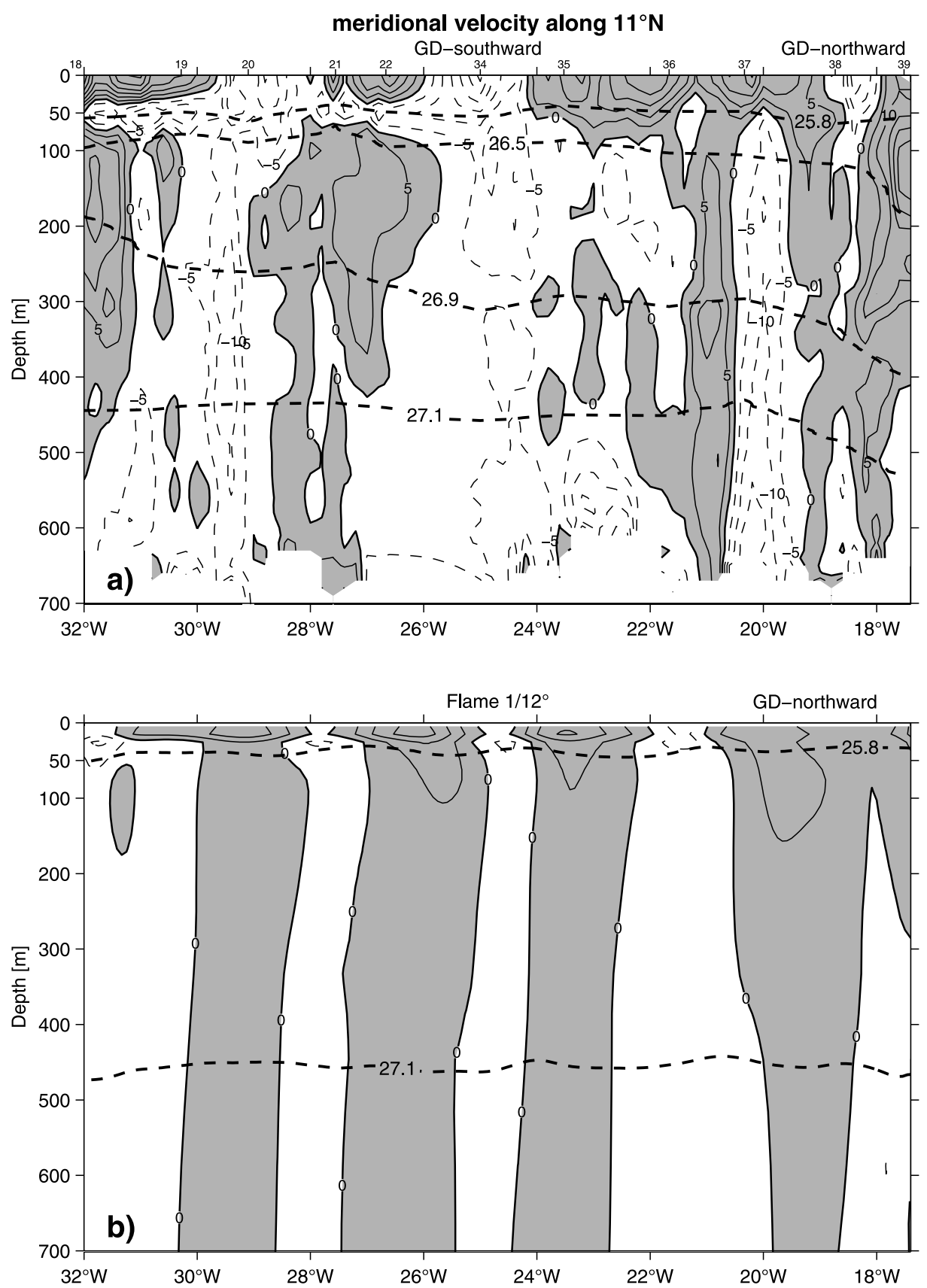

Figure 11. Distribution of zonal velocity in $\mathrm{cm} / \mathrm{s}$ in the upper $700 \mathrm{~m}$ (a) along about $11^{\circ} \mathrm{N}$ in October/ November 2002 from shipboard ADCP measurements and (b) along $11^{\circ} \mathrm{N}$ for November from the $1 / 12^{\circ}-$ FLAME model. Positive (northward) is shown in gray. Included are the density surfaces $\sigma_{\theta}=25.8$ and $27.1 \mathrm{~kg} / \mathrm{m}^{3}$ as thick dashed lines representing water mass boundaries. Two additional isopycnals $\left(\sigma_{\theta}=\right.$ 26.5 and $26.9 \mathrm{~kg} / \mathrm{m}^{3}$ ) are included in Figure 11a to show the doming. The northward and southward flow regions of the Guinea Dome (GD) are marked in the figure.

NICC reaches even up into the central water layer and is connected to the EUC and the NEUC. The oxygen distribution at about $27^{\circ} \mathrm{W}$ shows much higher oxygen values below $300 \mathrm{~m}$ depth at 1 to $3^{\circ} \mathrm{N}$ (Figure 2b). Hence the NICC acts as a source of oxygen rich water for the tropical low oxygen zone in the AAIW layer.

\subsection{Guinea Dome}

[46] North of $10^{\circ} 30^{\prime} \mathrm{N}$ at $24^{\circ} \mathrm{W}$ observations as well as model results show the southernmost component of the westward flow of the Guinea Dome (Figure 6). The section along $10-11^{\circ} \mathrm{N}$ in October/November 2002 can be used to investigate the meridional flow components of the Guinea Dome. In the surface layer northward flow was observed east of $24^{\circ} \mathrm{W}$ (Figure 11a) of about $2.8 \mathrm{~Sv}$ (Figure 12). The isopycnal $\sigma_{\theta}=25.8 \mathrm{~kg} / \mathrm{m}^{3}$ shows only a weak doming with the shallowest depth of about $45 \mathrm{~m}$ at $23^{\circ}$ to $24^{\circ} \mathrm{W}$ (Figure 11a). Two other isopycnals $\left(\sigma_{\theta}=26.5\right.$ and $26.9 \mathrm{~kg} / \mathrm{m}^{3}$ in Figure 11a) show the doming related to the northward and southward flow components somewhat 


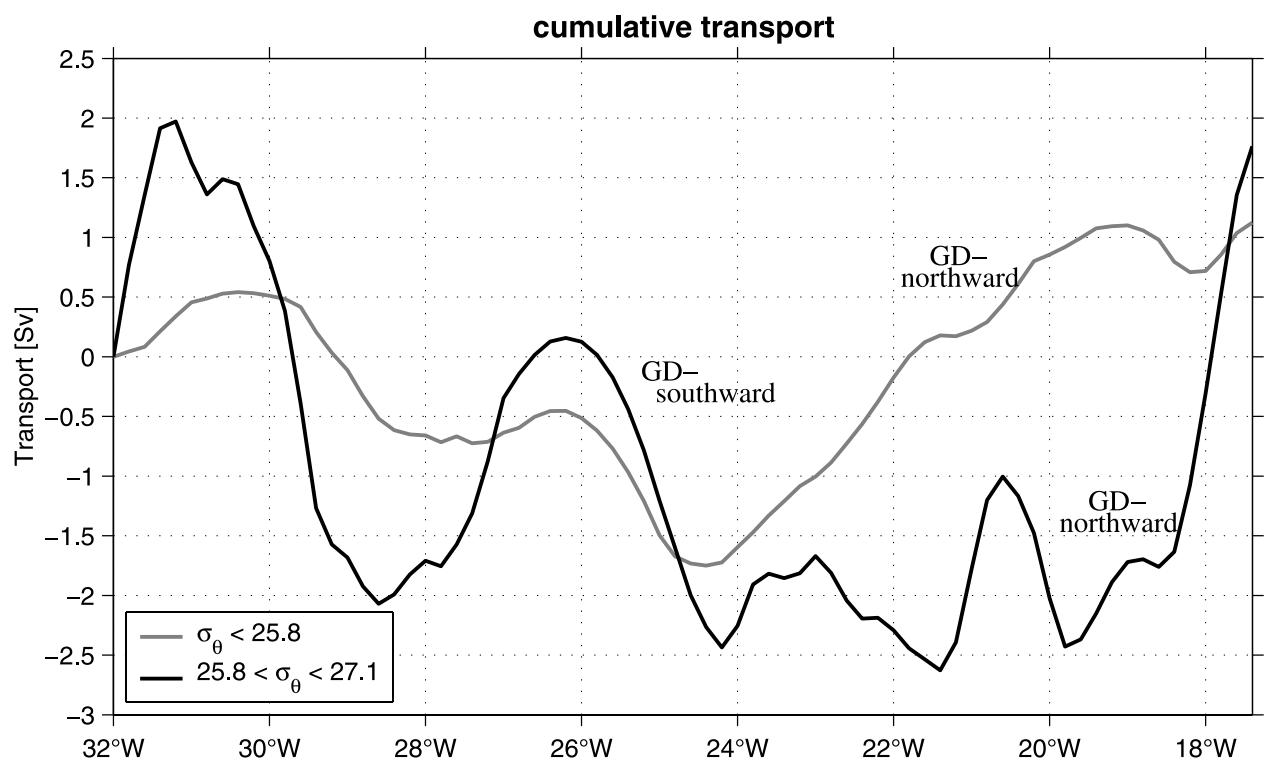

Figure 12. Cumulative volume transport in $\mathrm{Sv}$ (northward is positive) along the $11^{\circ} \mathrm{N}$ section for the layer surface to $\sigma_{\theta}=25.8 \mathrm{~kg} / \mathrm{m}^{3}$ and the density layer $\sigma_{\theta}=25.8$ to $27.1 \mathrm{~kg} / \mathrm{m}^{3}$. The northward and southward flow regions of the Guinea Dome (GD) in the selected layer are marked in the figure.

better. This doming is related to the reversal in flow direction in the upper layer. Siedler et al. [1992] described that thermal doming can be seen below $50 \mathrm{~m}$ depth, therefore the isopycnal $\sigma_{\theta}=25.8 \mathrm{~kg} / \mathrm{m}^{3}$ is too shallow to resolve a large doming signal. In the layer $\sigma_{\theta}=25.8$ to $27.1 \mathrm{~kg} / \mathrm{m}^{3}$ the northward transport is restricted to the region east of $20^{\circ} \mathrm{W}$ with a transport of $4 \mathrm{~Sv}$. When compared to the $24^{\circ} \mathrm{W}$ transport, it seems that the northern NECC current band almost completely turns north in the Guinea Dome, while the shallow southern NECC current band in October/ November 2002 continues eastward. Between $30^{\circ} \mathrm{W}$ and $24^{\circ} \mathrm{W}$ most of the northward transport is compensated by southward flow, hence these are the meridional components of Guinea Dome. The $1 / 12^{\circ}$-FLAME model, however, shows only a weak signature of the Guinea Dome (Figures $4 \mathrm{a}, 4 \mathrm{~b}$, and $11 \mathrm{~b}$ ). In the $11^{\circ} \mathrm{N}$ FLAME-model section for November a set of reversing north- and southward flows dominate the velocity distribution (Figure 11b).

[47] The profiling APEX float at $200 \mathrm{~m}$ depth described already for its eastward path in the NECC made its way into the Guinea Dome (Figure 3b). After the float had shifted northward into the nNECC in August 2001 it was advected eastward and than northward (Figure $3 \mathrm{~b}$ ) and reached it easternmost location at the end of 2001. Until November 2003 the float slowly circled near $12^{\circ} \mathrm{N}, 27^{\circ} \mathrm{W}$. Surprisingly, the float shifted to a more northern location at about $15^{\circ} \mathrm{N}$ during 2004, where the float stalled again. In February 2005 the float returned again southward to $13^{\circ} \mathrm{N}$ and than moved first eastward and than northward towards the low oxygen zone. Just at the end of the record presented here (28 August 2005, red cross in Figure 3b), the float was still cycling and turned westward and approached the Cape Verde Islands. This APEX float shows the northward shift of southern water masses crossing the equator, and demonstrated also the possible exchange in-between different current bands as well as the ability to leave the Guinea Dome northward. As can be seen from Figure 3b, the climatological mean dissolved oxygen value at the location of the float decreased with time except for the northern excursion during 2004. The float stayed for more than 3 years in the oxygen minimum zone and demonstrates that there is no large water exchange in this region.

[48] Backward integration in the FLAME model from water parcels reaching the Guinea Dome provides information on the origin of the water in the Guinea Dome (Figure 10). Model floats reaching the Guinea Dome at $13^{\circ} \mathrm{N}$ between $20^{\circ} \mathrm{W}$ and $24^{\circ} \mathrm{W}$ were all originating from the nNECC with a transfer at $22^{\circ}$ to $32^{\circ} \mathrm{W}$ from the NEUC. The floats which were integrated backward from $24^{\circ}$ to $25^{\circ} \mathrm{W}$ can be traced back into the nNECC in the western tropical Atlantic. The depth of the float tracks (Figure 10) demonstrates the upward shift of the isopycnals in the Guinea Dome region. The model floats at 50 to $150 \mathrm{~m}$ depth at $13^{\circ} \mathrm{N}$ had been as deep as $310 \mathrm{~m}$ in the NECC.

[49] As not many sections are available it seems worthwhile to investigate whether there is still a signature of the Guinea Dome on a section south of the dome. The ADCPsection from R/V L'Atalante in February/March 1993 (from the joint archive for shipboard ADCP, Hawaii; status July 2004) crossed the Guinea Dome to the south of the center at $7.5^{\circ} \mathrm{N}$. Also in this section (Figure 13a) the banded structure is visible with southward components between $29^{\circ} \mathrm{W}$ and $20^{\circ} \mathrm{W}$ in the surface layer and $29^{\circ} \mathrm{W}$ to $23^{\circ} \mathrm{W}$ in the subsurface layer. The transports (Figure 13b) are weaker than in October/November 2002. In the surface layer above $\sigma_{\theta}=25.8 \mathrm{~kg} / \mathrm{m}^{3}$ the northward transport between $20^{\circ} \mathrm{W}$ and $18^{\circ} \mathrm{W}$ is only $1 \mathrm{~Sv}$ and in the layer $\sigma_{\theta}=25.8 \mathrm{~kg} / \mathrm{m}^{3}$ to $450 \mathrm{~m}$ or $\sigma_{\theta}=27.1 \mathrm{~kg} / \mathrm{m}^{3}$ when this isopycnal is less than $450 \mathrm{~m}$ deep is about $2.5 \mathrm{~Sv}$ between $23^{\circ} \mathrm{W}$ and $19^{\circ} \mathrm{W}$. The weaker transports compared to October/November 2002 is due to the more southern location of the L'Atalante section. The nNECC current band at $8^{\circ}$ to $10^{\circ} \mathrm{N}$ in not incorporated in the $7.5^{\circ} \mathrm{N}$ transport measurements. Furthermore, the 1993section is a quite old ADCP-section and navigation as well as calibration might have been not so good as today. Therefore, this section has to be regarded with caution. 

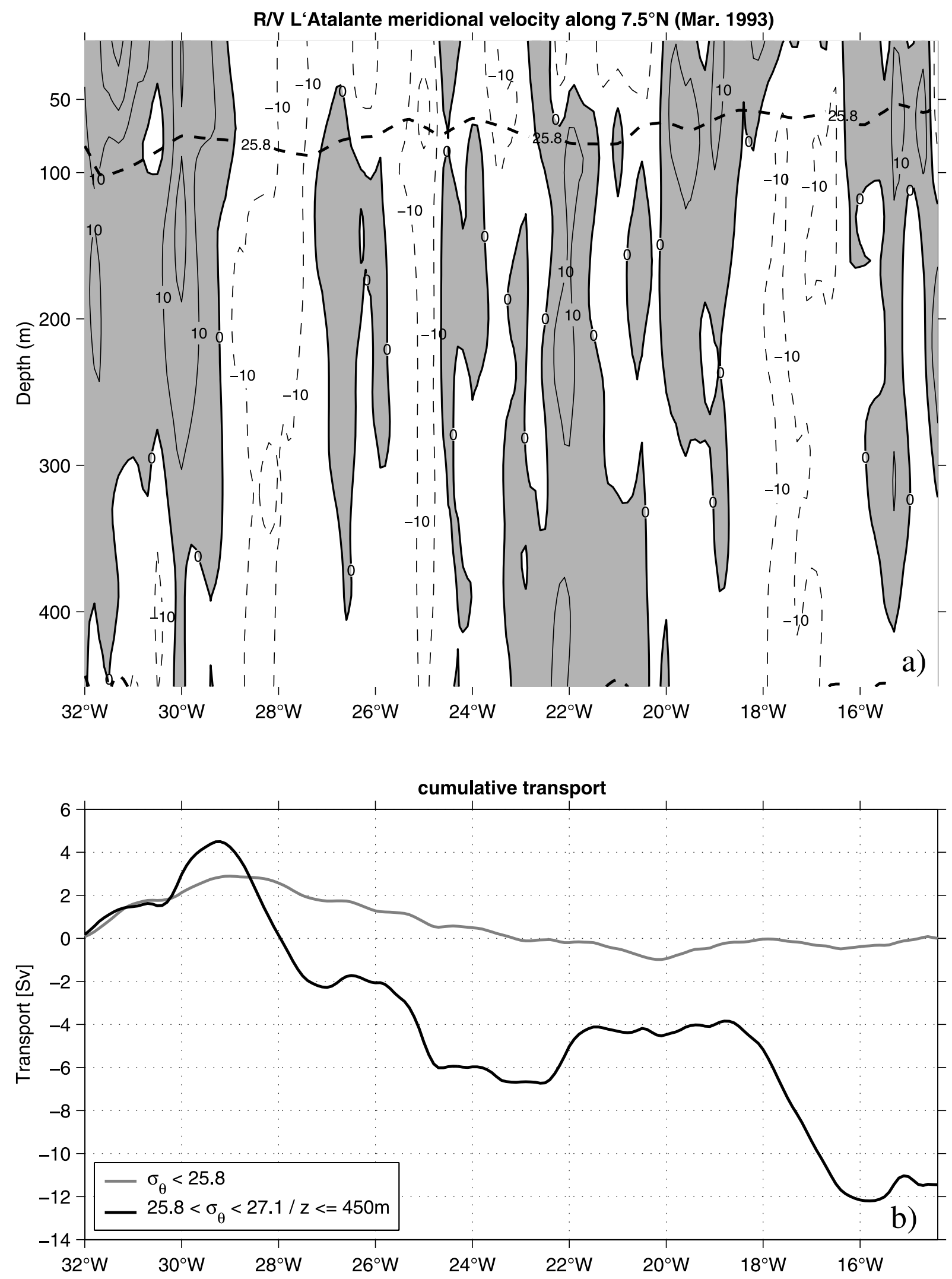

Figure 13. Distribution of zonal velocity in $\mathrm{cm} / \mathrm{s}$ in the upper $450 \mathrm{~m}$ (a) along about $7.5^{\circ} \mathrm{N}$ in February/ March 1993 from shipboard ADCP measurements, positive (northward) is shown in gray and (b) cumulative volume transport in $\mathrm{Sv}$ (northward is positive) along the $7.5^{\circ} \mathrm{N}$ section for the layer surface to $\sigma_{\theta}=25.8 \mathrm{~kg} / \mathrm{m}^{3}$ and the density layer $\sigma_{\theta}=25.8$ to $450 \mathrm{~m}$ or $27.1 \mathrm{~kg} / \mathrm{m}^{3}$ where available. Included in Figure 13a are the density surfaces $\sigma_{\theta}=25.8$ and $27.1 \mathrm{~kg} / \mathrm{m}^{3}$ (where available) as thick dashed lines representing water mass boundaries. 
Nevertheless, also the L'Atalante ADCP-section in February/March 1993 shows the weak signature of the Guinea Dome and the banded structure of the flow field.

\subsection{Southeastern Subtropical Gyre}

[50] The $1 / 12^{\circ}$-model simulation shows the outcropping of the isopycnal $\sigma_{\theta}=25.0 \mathrm{~kg} / \mathrm{m}^{3}$ at about $22^{\circ}$ to $24^{\circ} \mathrm{N}$ (Figure 4a). The saline water forms the saline Salinity Maximum Water and is carried southwestward with the NEC. An eastward return of the saline water is observed in the nNECC at about $8^{\circ} \mathrm{N}$ and somewhat weaker in the NECC at about $4^{\circ} \mathrm{N}$ (Figure 4a).

[51] The section at about $27^{\circ} \mathrm{W}$ in July/August 2003 as well as the July $1 / 12^{\circ}$-FLAME model (Figure 8 ) show that the NEC is organized in several current bands but not in a well organized main current band. The southern band is shallow and located at $16^{\circ} \mathrm{N}$ to $22^{\circ} \mathrm{N}$ in the observations and $14^{\circ} \mathrm{N}$ to $20^{\circ} \mathrm{N}$ in the model (Figure 8). The transports in this southern band is only about $2 \mathrm{~Sv}$ above $\sigma_{\theta}=25.8 \mathrm{~kg} / \mathrm{m}^{3}$ and $3.5 \mathrm{~Sv}$ between $\sigma_{\theta}=25.8 \mathrm{~kg} / \mathrm{m}^{3}$ and $300 \mathrm{~m}$ depth. The northern band is located north of $22^{\circ} \mathrm{N}$ and reaches to depth of more than $100 \mathrm{~m}$ with velocities exceeding $10 \mathrm{~cm} / \mathrm{s}$. The altimeter data (Figure 3a) as well as the model results (Figure 4) corroborate that the NEC current bands are disturbed by eddy-like features. A possible reason is, that the eastern boundary current is unstable [Siedler and Onken, 1996], resulting in a meandering jet surrounded by persistent eddies. In an investigation on subduction in the eastern North Atlantic Weller et al. [2004] described from in-situ data that eddy variability has a large influence. These eddies are a potential source of water exchange between the subtropical and the tropical gyre. The strong gradients in salinity as well as in oxygen (Figure 2) indicate that in general the exchange at the CVFZ is weak and that the inflow mainly takes place further south by the eastward currents.

\section{Conclusion}

[52] Here recent current measurements and hydrographic observations were combined with earlier results and compared with numerical simulations to better understand the upper ocean circulation and water mass distribution in the eastern tropical Atlantic. Although several components of the flow field are known, there still exist a lot of basic questions, with regard to the variability of the circulation and its influence on climate change observations.

[53] An eastward nNECC band exists in our observations as well as in the annual mean $1 / 12^{\circ}$-FLAME model velocity distribution at 8 to $10^{\circ} \mathrm{N}$. This second NECC band had been described already in the western tropical Atlantic from modelling as well as observational studies [Schott and Böning, 1991; Urbano et al., 2005; Richardson and Reverdin, 1987]. Model float data show that in the region $22^{\circ}$ to $32^{\circ} \mathrm{W}$ there is strong exchange between the NECC/ NECC and the nNECC, even with a westward detour on its way north. The model velocity on the isopycnal $\sigma_{\theta}=$ $25.0 \mathrm{~kg} / \mathrm{m}^{3}$ (Figure $4 \mathrm{a}$ ) shows a flow from the NECC to the nNECC with a westward detour at $28^{\circ}$ to $32^{\circ} \mathrm{W}$. A real float at $200 \mathrm{~m}$ depth also showed the northward transition at $28^{\circ} \mathrm{W}$, although with only a weak westward shift. The northward shift of the float in November 2000 was connected to an eddy-like SSHA feature. This feature was moving slowly westward, however too slow to be a Rossby wave or a tropical instability wave. The model floats in monthly mean model velocity fields showed enhanced northward shift during boreal summer months. Therefore, tropical instability waves (TIW) might play an important role in the transfer from the NECC/NEUC to the nNECC. As TIW's are spreading westward with a mean velocity of about $22 \mathrm{~cm} / \mathrm{s}$ [Foltz et al., 2004], the larger westward detour in the model floats (Figure 10) compared to the path of the one real float might be connected to the fast westward spreading of the TIW's.

[54] The velocity observations in October/November 2002 show a weak signature of the Guinea Dome. The monthly mean $1 / 12^{\circ}$-FLAME model results show even smaller velocities than the direct observations. This is due to the large variability as observed, e.g., in the altimeter observations (Figure 3a). This variability leads to smaller velocities in the monthly mean modeled distributions compared to direct observations. Despite the existing variability, transport estimates for the Guinea Dome from the direct observations are possible; in November 2002 the Guinea Dome transport from direct observations was about $2.8 \mathrm{~Sv}$ above $\sigma_{\theta}=25.8 \mathrm{~kg} / \mathrm{m}^{3}$ and $4 \mathrm{~Sv}$ between $\sigma_{\theta}=25.8$ and $27.1 \mathrm{~kg} / \mathrm{m}^{3}$. In February/March 1993 northward transport near Africa was weaker than in November 2002. However, this section crossed the Guinea Dome south of its center and missed the contribution from the nNECC. Very little is known about the off-coastal upwelling regimes as in the Guinea Dome. The upwelling in the western Guinea Dome region as described by Schott et al. [2004] is reflected in the uplift of the isopycnals in the water mass distribution especially at 100 to $200 \mathrm{~m}$ depth $\left(\sigma_{\theta}=26.7 \mathrm{~kg} / \mathrm{m}^{3}\right.$ in Figure $2 b$ ).

[55] The mean flow regimes of the NEC as region of subduction, the Guinea Dome as upwelling region as well as the nSEC, the NECC and the nNECC at $8^{\circ}$ to $10^{\circ} \mathrm{N}$ as well as its interaction are shown in Figure 14. These current bands can all be recognized in the observations; however, as indicated in the satellite data as well as in the model simulation the flow field is strongly influenced by eddylike features. These eddy-like features will influence the measurement along single sections. This can be seen from the current vectors observed in October/November 2002 overlaid on the sea surface height (Figure 3a). The $1 / 12^{\circ}$ FLAME model reproduces all the major current bands, although at depth the model velocities are lower than the observations. A float at $200 \mathrm{~m}$ depth was carried by the NECC eastward and was trapped in the Guinea Dome region for more than 3 years. This nicely demonstrates that there is no large water exchange in this region.

[56] The tropical-subtropical eastern North Atlantic has low oxygen layers (Figure $3 \mathrm{~b}$ ) in the central water as well as the AAIW layer south of the CVFZ. As the water south of the CVFZ shows characteristics of waters from southern hemispheric South Atlantic Central Water and AAIW, the supply of oxygen is accomplished mainly by current bands transporting southern water masses. The largest oxygen minimum is located at the boundary between the central water and the AAIW. At the locations of the NEUC and the NECC relative high oxygen values are observed in the hydrographic measurements. Consequently, the NEUC and 


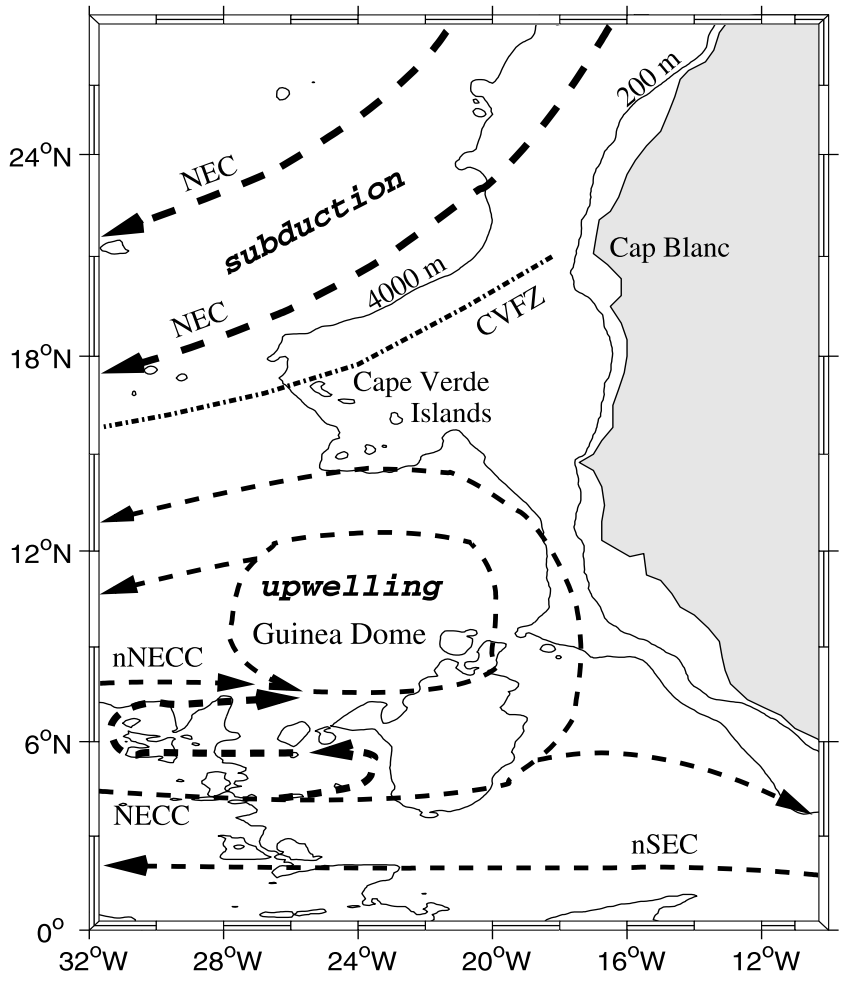

Figure 14. Map of the investigation area with the depth contours of $200 \mathrm{~m}$ and $4000 \mathrm{~m}$ included. Shown is a schematic of the large scale near surface flow field (dashed lines). Marked are the North Equatorial Current (NEC), the North Equatorial Countercurrent (NECC), the northern NECC (nNECC) band at 8 to $10^{\circ} \mathrm{N}$ and the connection between these two, as well as the northern band of the South Equatorial Current (nSEC).

the NECC are major sources of oxygen richer water for the low-oxygen regions in the central water layer of the northeastern tropical Atlantic. The nNECC is made up with saline (Figure $4 \mathrm{a}$ ) and oxygen rich (Figure $2 \mathrm{~b}$ ) water from the southern hemisphere but with an admixture from the northern hemisphere. The nNECC also carries oxygen rich water to the low oxygen layer of the central water. Hence, the nNECC is responsible to supplement also water from northern hemispheric water masses into the Guinea Dome region. In the Antarctic Intermediate Water layer the Northern Intermediate Countercurrent acts as oxygen source for the oxygen minimum zone between 5 and $20^{\circ} \mathrm{N}$.

[57] Compared to the eastern tropical Pacific the eastern Atlantic is more oxygenated in the minimum zone. One reason might be the inflow of oxygen rich water from the west in the NEUC, the nNECC at $8^{\circ}$ to $10^{\circ} \mathrm{N}$ and the NICC. The corresponding current bands in the Pacific have to travel much longer distances and might contribute less oxygen to the oxygen minimum zones. Other processes like upwelling and biogeochemical processes [e.g., Oudot, 1989] might be of importance, too. Therefore, a large multidisciplinary research initiative is proposed at the Leibniz Institute of Marine Sciences in Kiel to investigate all possible contributions to maintain the oxygen minimum zones and will hopefully add new insight into the mechanisms of the low oxygen layers in the eastern tropical oceans.
[58] Acknowledgments. Financial support was received through the IFM-GEOMAR Kiel, Germany, and by the BMBF projects CLIVAR-II (03F0377B) and ARGO. The R/V Meteor cruise M55 (P. I. Douglas Wallace) was funded by the Deutsche Forschungsgemeinschaft (DFG, grant WA 1434/3). The altimeter products were produced by Ssalto/Duacs as part of the Environment and Climate EU Enact project (EVK2-CT2001-00117) and distributed by Aviso with support from Cnes (http://www.aviso. oceanobs.com). The NOAA ship Ron Brown 2003 cruise (chief scientists John Bullister and Nicolas Gruber) was completed under the NSF/NOAAfunded Repeat Hydrography Program and data (ADCP P. I. Eric Firing and Julia M. Hummon and hydrography P. I. Gregory Johnson) were made available through the CLIVAR and Carbon Hydrographic Data Office, La Jolla, California, USA (status January 2005). The model experiments have been performed using the facilities and services of the Deutsches Klimarechenzentrum (DKRZ), Hamburg.

\section{References}

Arhan, M., A. Colin de Verdiere, and L. Memery (1994), The eastern boundary of the subtropical North Atlantic, J. Phys. Oceanogr., 24, $1295-1316$.

Barnier, B., L. Siefridt, and P. Marchesiello (1995), Thermal forcing for a global ocean circulation model using a three-year climatology of ECMWF analysis, J. Mar. Sys., 6, 363-380.

Böning, C., and F. O. Bryan (1996), Large-scale transport processes in high-resolution circulation models, in The Warm Water Sphere of the North Atlantic Ocean, edited by W. Krauss, pp. 91-128, Gebrüder Bornträger, Berlin.

Borges, R., A. Hernandez-Guerra, and L. Nykjaer (2004), Analysis of sea surface temperature time series of the south-eastern North Atlantic, Int. J. Remote Sens., 25, 869-891.

Bourles, B., M. D’Orgeville, G. Eldin, Y. Gouriou, R. Chuchla, Y. D. Penhoat, and S. Arnault (2002), On the evolution of the thermocline and subthermocline eastward currents in the Equatorial Atlantic, Geophys. Res. Lett., 29(16), 1785, doi:10.1029/2002GL015098.

Boyer, T. P., and S. Levitus (1997), Objective analyses of temperature and salinity for the world ocean on a 1/4 degree grid, NOAA Atlas NESDIS 11, U.S. Govt. Print. Off., Washington, D. C

Brandt, P., and C. Eden (2005), Annual cycle and interannual variability of the mid-depth tropical Atlantic Ocean, Deep Sea Res., I, (52), 199219.

Bryan, F. O., and W. R. Holland (1989), A high resolution simulation of the wind- and thermohaline-driven circulation in the North Atlantic Ocean: Parametrization of small-scale processes, in Proceedings of 'Aha Huliko'a, Hawaian Winter Workshop, edited by P. Müller and D. Henderson, Hawaii Inst. Geophys. Spec. Publ., 99-115.

Csanady, G. T. (1987), What controls the rate of equatorial warm water mass formation?, J. Mar. Res., 45, 513-532.

Cummins, P. F., G. Holloway, and A. E. Gargett (1990), Sensitivity of the GFDL ocean general circulation model to a parameterization of vertical diffusion, J. Phys. Oceanogr., 20, 817-830.

Czeschel, L. (2004), The role of eddies for the deep water formation in the Labrador Sea, Ph.D. thesis, 101 pp., Christian-Albrechts Univ., Kiel, Germany.

Döös, K. (1999), Influence of Rossby waves on the seasonal cycle in the tropical Atlantic, J. Geophys. Res., 104, 29,591-29,598.

Emery, W. J., and J. Meincke (1986), Global water masses: summary and review, Oceanol. Acta, 9, 383-391.

Foltz, G. R., S. A. Grodsky, and J. A. Carton (2003), Seasonal mixed layer heat budget of the tropical Atlantic Ocean, J. Geophys. Res., 108(C5), 3146, doi:10.1029/2002JC001584.

Foltz, G. R., J. A. Carton, and E. P. Chassignet (2004), Tropical instability vortices in the Atlantic Ocean, J. Geophys. Res., 109, C03029, doi:10.1029/2003JC001942.

Fonseca, C. A., G. J. Goni, W. E. Johns, and E. J. D. Campos (2004), Investigation of the North Brazil Current retroflection and North Equatorial Countercurrent variability, Geophys. Res. Lett., 31, L21304, doi:10.1029/2004GL020054.

Grodsky, S. A., and J. A. Carton (2002), Surface drifter pathways originating in the equatorial Atlantic cold tongue, Geophys. Res. Lett., 29(23), 2147, doi:10.1029/2002GL015788.

Gouretski, V. V., and K. P. Koltermann (2004), WOCE global hydrographic climatology, Ber. 35, 50 pp., Bundesamtes für Seeschifffahrt und Hydrographie, Hamburg, Germany.

Hagen, E. (2001), Northwest African upwelling scenario, Oceanol. Acta, 24, suppl., S113-S128.

Jochum, M., P. Malanotte-Rizzoli, and A. Busalacchi (2004), Tropical instability waves in the Atlantic Ocean, Ocean Modell., 7, 145163.

Joyce, T. M. (1989), On in situ "calibration" of shipboard ADCPs, J. Atmos. Oceanic Technol., 6, 169-172. 
Kraus, E. B., and J. S. Turner (1967), A one-dimensional model of the seasonal thermocline laboratory experiment and its interpretation, Tellus, 19, $88-97$.

Levin, L. A. (2003), Oxygen minimum zone benthos: Adaptation and community response to hypoxia, in Oceanography and Marine Biology: An Annual Review 2003, vol. 41, edited by R. N. Gibson and R. J. A. Atkinson, pp. 1-45, Taylor and Francis, Philadelphia, Pa.

Luyten, J. R., and H. Stommel (1986), Gyres driven by combined wind and buoyancy flux, J. Phys. Oceanogr., 16, 1551-1560.

Molinari, R. L., S. L. Garzoli, E. J. Katz, D. E. Harrison, P. L. Richardson, and G. Reverdin (1986), A synthesis of the first GARP Global Experiment (FGGE) in the equatorial Atlantic Ocean, Prog. Oceanogr., 16, $91-$ 112 .

O'Connor, B. M., R. A. Fine, and D. B. Olson (2005), A global comparison of subtropical Underwater formation rates, Deep Sea Res., I, (52), 15691590 .

Oudot, C. (1989), $\mathrm{O}_{2}$ and $\mathrm{CO}_{2}$ balances approach for estimating biological production in the mixed layer of the tropical Atlantic Ocean, J. Mar. Res., 47, 385-409.

Pacanowski, R. (1995), MOM 2 documentation, user's guide and reference manual, GFDL Tech. Rep., 2, 123 pp.

Redi, M. H. (1982), Oceanic isopycnal mixing by coordinate rotation, J. Phys. Oceanogr., 12, 1154-1158.

Richardson, P. L., and G. Reverdin (1987), Seasonal cycle of velocity in the Atlantic North Equatorial Countercurrent as measured by surface drifters, current meters, and ship drifts, J. Geophys. Res., 92, 36913708

Schafstall, J. (2003), Oberflächennahe Zirkulation des tropischen Atlantiks bei $10^{\circ} \mathrm{N}$ im Herbst 2002, diploma thesis, 55 pp., Christian-AlbrechtsUniv., Kiel, Germany.

Schott, F. A., and C. Böning (1991), The WOCE model in the western equatorial Atlantic: Upper layer circulation, J. Geophys. Res., 96, $6993-$ 7004

Schott, F. A., L. Stramma, and J. Fischer (1995), The warm water inflow into the western tropical Atlantic boundary regime, spring 1994, J. Geophys. Res., 100, 24,745-24,760.

Schott, F. A., J. Fischer, and L. Stramma (1998), Transports and pathways of the upper-layer circulation in the western tropical Atlantic, J. Phys Oceanogr., 28, 1904-1928.

Schott, F. A., P. Brandt, M. Hamann, J. Fischer, and L. Stramma (2002), On the boundary flow off Brazil at $5-10^{\circ} \mathrm{S}$ and its connection to the interior tropical Atlantic, Geophys. Res. Lett., 29(17), 1840, doi:10.1029/ 2002GL014786.

Schott, F. A., J. P. McCreary, and G. Johnson (2004), Shallow overturning circulations of the tropical-subtropical oceans, in Earth's Climate: The Ocean Atmosphere Interaction, edited by C. Wang, S.-P. Xie, and J. A. Carton, pp. 261-304, AGU, Washington, D. C.
Siedler, G., and R. Onken (1996), Eastern Recirculation, in The Warm Water Sphere of the North Atlantic Ocean, edited by W. Krauss, pp. 339-364, Gebrüder Bornträger, Berlin.

Siedler, G., N. Zangenberg, R. Onken, and A. Morliere (1992), Seasonal changes in the tropical Atlantic Ocean: Observations and simulations of the Guinea Dome, J. Geophys. Res., 97, 703-715.

Stramma, L. (1984), Geostrophic transport in the Warm Water Sphere of the eastern subtropical North Atlantic, J. Mar. Res., 42, 537-558.

Stramma, L., and F. Schott (1999), The mean flow field of the tropical Atlantic Ocean, Deep Sea Res. II, 46, 279-303.

Stramma, L., and G. Siedler (1988), Seasonal changes in the North Atlantic Subtropical Gyre, J. Geophys. Res., 93, 8111-8118.

Stramma, L., J. Fischer, P. Brandt, and F. Schott (2003), Circulation, variability and near-equatorial meridional flow in the central tropical Atlantic, in Interhemispheric Water Exchange in the Atlantic Ocean, Oceanogr. Ser., vol. 68, edited by G. J. Goni and P. Malanotte-Rizzoli, pp. 1-22, Elsevier, New York

Stramma, L., M. Rhein, P. Brandt, M. Dengler, C. Böning, and M. Walter (2005), Upper ocean circulation in the western tropical Atlantic in boreal fall 2000, Deep Sea Res., I, (52), 221-240.

Tomczak, M., and J. S. Godfrey (1994), Regional Oceanography: An Introduction, 422 pp., Elsevier, New York.

Tsuchiya, M., L. D. Talley, and M. S. McCartney (1992), An eastern Atlantic section from Iceland southward across the equator, Deep Sea Res., 39, 1885-1917.

Urbano, D. F., M. Jochum, and I. C. A. da Silveira (2005), Rediscovering the second core of the Atlantic NECC, Ocean Modell., in press.

Wallace, D. R., and H. W. Bange (2004), Introduction to special section: Results of the Meteor 55: Tropical SOLAS expedition, Geophys. Res. Lett., 31, L23S01, doi:10.1029/2004GL021014.

Weller, R. A., P. W. Furey, M. A. Spall, and R. E. Davis (2004), The largescale context for oceanic subduction in the northeast Atlantic, Deep Sea Res. I, 51, 665-699.

Willebrand, J., B. Barnier, C. Böning, C. Dieterich, P. Herrmann, P. Killworth, C. Le Provost, Y. Jia, J.-M. Molines, and A. L. New (2001), Circulation characteristics in three eddy-permitting models of the North Atlantic, Prog. Oceanogr., 48, 123-161.

Zenk, W., B. Klein, and M. Schröder (1991), Cape Verde Frontal Zone, Deep Sea Res., 38, suppl. I, S505-S530.

Zhang, D., M. J. McPhaden, and W. E. Johns (2003), Observational evidence for flow between the subtropical and tropical Atlantic: The Atlantic tropical cells, J. Phys. Oceanogr., 33, 1783-1797.

S. Hüttl, J. Schafstall, and L. Stramma, Leibniz-Institut für Meereswissenschaften an der Universität Kiel, IFM-GEOMAR, Düsternbrooker Weg 20,24105 Kiel, Germany. (1stramma@ifm-geomar.de) 